\title{
ENTRE PERFORMANCES E PRÓTESES, OS PÉS: CIRCUITOS TECNO- ORGÂNICOS DA ERÓTICA DOS FRAGMENTOS CORPORAIS MASCULINOS NA PORNOGRAFIA ONLINE ${ }^{1}$
}

\author{
Between performances and prostheses, the feet: \\ techno-organic circuits of erotic male body fragments in online pornography
}

Ribamar José de Oliveira Junior ${ }^{2}$

\begin{abstract}
RESUMO: Este trabalho tem como objetivo analisar a performance na cena-ação da produção pornográfica online do fetiche da podolatria masculina. Desse modo, utilizei a etnografia de tela como recurso metodológico, ao lado do diário de campo diante dos pontos potenciais investigados e da observação dos planos cinematográficos do vídeo, no sentido de me envolver nas imagens do fetiche em três sites de conteúdo pornográfico online: My Friends Feet, Str8crushFeet e Lads Feet. Assim, diante de uma perspectiva foucaultiana da erotização do poder e dessexualização do prazer, analiso que as narrativas pornográficas podem tecer construções do gênero tido como masculino por meio das estéticas do grotesco e das eróticas do nojo, sobretudo, nas lógicas do fetiche entre a dominação e a submissão entre os homens diante do ato de adorar os pés. Ao analisar as cenas do recorte de três vídeos disponíveis nos sites, considero o fetiche podolatria a partir das narrativas do excesso entre a dimensão coreográfica, confessional e protética.
\end{abstract}

Palavras-chaves: Gênero e Sexualidades. Masculinidades. Fetiche. Pornografia.

\begin{abstract}
This work aims to analyze the performance in the action scene of the online pornographic production of the male foot fetish. In this way, I used screen ethnography as a methodological resource, alongside the field diary in view of the potential points investigated and observation of the video's cinematic plans, in order to get involved in the fetish images on three online pornographic sites: My Friends Feet, Str8crushFeet and Lads Feet. Thus, in view of a foucaultian perspective of the erotization of power and the desexualization of pleasure, I analyze that pornographic narratives can weave constructions of the gender considered to be masculine

\footnotetext{
${ }^{1}$ Trabalho desenvolvido a partir do trabalho apresentado em formato de resumo simples no Grupo de Trabalho (GT) "Foucault" do evento "II Encontro Nietzsche e Foucault: Diálogos", realizado entre os dias 20 a 24 de julho de modo remoto pela Universidade Estadual do Piauí (UESPI).

${ }^{2}$ Doutorando em Comunicação e Cultura pela Universidade Federal do Rio de Janeiro (UFRJ). Mestre em Ciências Sociais pela Universidade Federal do Rio Grande do Norte (UFRN). Especialista em Gênero e Sexualidade na Educação pela Universidade Federal da Bahia (UFBA). Aperfeiçoando em Tecnologias Digitais na Educação pela Universidade Federal do Ceará (UFC). Graduado em Comunicação Social - Jornalismo pela Universidade Federal do Cariri (UFCA). E-mail: ribamar@ufrj.br.
} 
through the aesthetics of the grotesque and the erotic of disgust, above all, in the logic of fetish between domination and submission among men to the act of worshiping the feet. When analyzing the cut scenes of three videos available on the websites, I consider foot fetish fetishism based on the narratives of the excess between the choreographic, confessional and prosthetic dimensions.

Keywords: Gender and Sexualities. Masculinities. Fetish. Pornography.

\section{INTRODUÇÃO, NA CAMA COM FOUCAULT}

Em uma das páginas do livro "SEX”, escrito por Madonna com fotografias de Steven Meisel e cenas de Fabien Baron, editado pela Glenn O’Brien e lançado no dia 21 de outubro de 1992 pela Warner Books, Maverick Books e Callaway Books, há uma citação descrita pela personagem sadomasoquista Dita Parlo, incorporada pela cantora através de várias fantasias sexuais, que pode ser lida com o sussurro dela na faixa "Erotica": "only the one who hurt you, can confort you. Only the one who inflicts the pain can take it away". Assim, em uma das fotografias do livro Dita retrata o fetiche da podolatria, na qual aparece com o dedão de um dos modelos na boca enquanto segura o pé com as duas mãos. Como explica Gusmão (2019) a obra da cantora traz o que seria um hedonismo contemporâneo através do reflexo da cultura pop e dos valores pós-modernos, sobretudo, na forma com que traduz as experiências sensoriais na expressão de um tempo.

Figura 1 - Página do livro Sex da Madonna com representação do fetiche da podolatria.

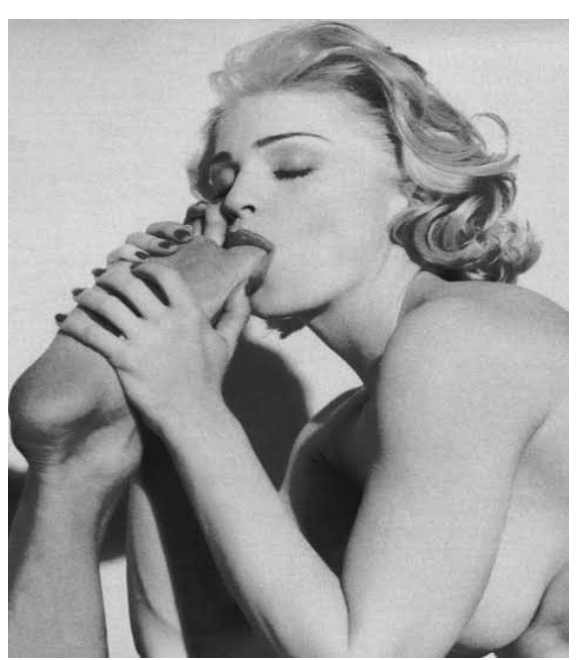

Fonte: Christinas Photo Site ${ }^{4}(2016)$

Assim, 27 anos depois, Madonna no videoclipe da faixa "Medellin" do seu décimo quarto álbum, “Madame X”, lançado no dia 14 de junho de 2019 pela Interscope Records, produzida em

\footnotetext{
3 “Apenas aquele que te machucou, pode te confortar. Só quem inflige a dor pode tirá-la” (tradução nossa).

${ }^{4}$ Link de acesso ao site: <https://christinasphotosite.wordpress.com/2016/02/04/madonnas-sex-book/>
} 
parceria com o colombiano Maluma e dirigida Diana Knust, a cantora aparece no espectro da madame que possui várias personas e traz o jogo de identidades e a busca da liberdade. Desse modo, o videoclipe possui leves referências sadomasoquistas e, em uma das cenas, Madonna aparece ao lado de Maluma e lambe o dedão do pé do cantor. Ao relacionar que as imagens de Madonna aparecem na prerrogativa de que o sexo se constitui nas relações de poder, Gusmão (2019) demonstra como o fetiche perpassa o livro, sendo este visto pelo autor como uma “expressão legítima desta ideia foucaultiana, uma vez que, ao ter se tornado um ícone da cultura pop, Madonna assumiu uma posição discursiva que lhe permitiu jogar com os fetiches na condição de polo dominante" (GUSMÃO, 2019, p. 83).

Figura 2 - Cena do videoclipe de Medellín em que Madonna lambe o pé de Maluma.

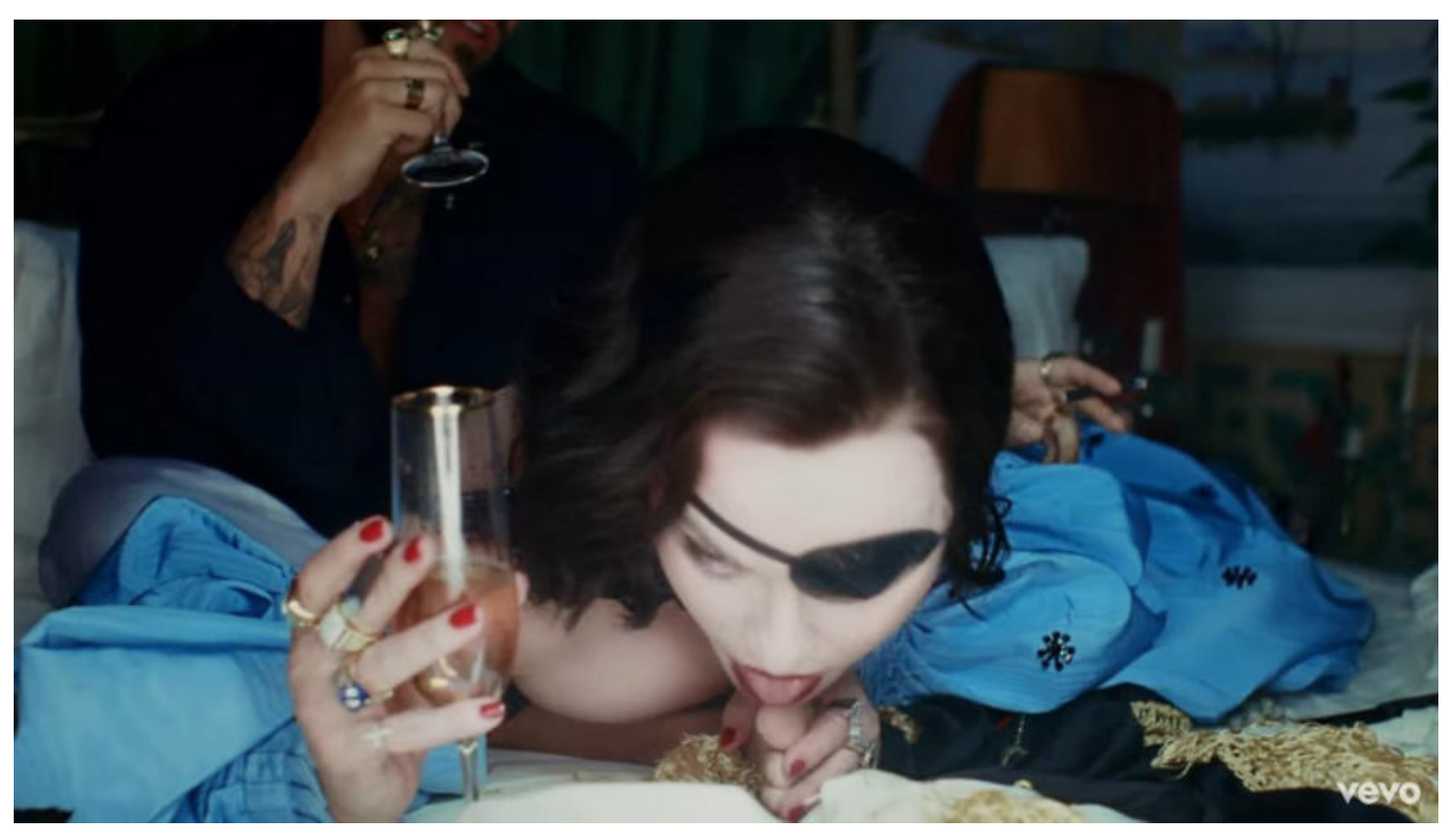

Fonte: Youtube ${ }^{5}$ (2019).

Diante disso, após folhear o livro da Madonna e reler sobre o dispositivo da sexualidade, decidi procurar detalhes sobre Michel Foucault e acabei encontrando as derivas deste trabalho. Em algumas páginas ${ }^{6}$, encontro possíveis declarações de que o filósofo era praticante de sadomasoquismo, o que em um primeiro momento me surpreende. Digo isso, pois vejo Foucault de óculos de grau e não com os dildos de Preciado (2014) no corpo. Moralista, diria eu, mas confesso que a escorregadia estereotipagem faz com que as bichas millenials às vezes pensem

\footnotetext{
${ }^{5}$ Link de acesso ao videoclipe: $<$ https:/ $/$ www.youtube.com/watch?v $=x A x N a L A R 2 t o>$.

6 Dentre algumas páginas, destaco este arquivo digitalizado do Acervo Globo. Link de acesso: < https://acervo.oglobo.globo.com/fatos-historicos/em-1984-morre-filosofo-michel-foucault-9910243 >
} 
Foucault como apenas uma maricona que lia livros, a exemplo das personas de Madonna penso se ele poderia ter sido podólatra. Nesse último caso, algumas leituras que tenho feito sobre a pornografia e alguns vídeos que tenho assistido diante das representações do fetiche da podolatria masculina têm me levado aos pés dos homens sobre uma inquietação, principalmente, diante do que há na narrativa do desejo entre a espetacularidade da humilhação e a subserviência do ato pelo excesso das imagens virtualizadas.

Ao levar em consideração o que Lopes (2020) traz sobre o que escrever sobre a pornografia quando a mesma está ao alcance de qualquer pessoa, reflito a partir do que o autor pontua sobre os filmes pornôs gays de que ele só consegue considerar as simulações de abuso como jogos, talvez por conta da má atuação. Porém, no caso dos filmes que não fujam do corpo com os seus fluidos, as suas texturas e os seus contornos, como pensar as imagens da fantasia e do abjeto quando os desejos estão no mesmo patamar, entrelaçados pela representação da relação situada no contexto do jogo de poder pela midiatização das corporalidades na narrativa pornográfica? Assim, este texto se rebaixa ao chão para sentir a textura e o contorno da forma como a realidade pode ser melhor do que a fantasia, no movimento fetichista geralmente inverso da pornografia, em que a fantasia é melhor do que a realidade.

Desse modo, trago o que Piscitelli (2009) destaca sobre a importância da internet na disseminação das convenções relacionadas ao erotismo como instrumento pedagógico, tendo em vista que a rede pode afirmar o que pode ser tido como normalidade e promover a integração social pela midiatização entre as pessoas que têm fantasias e praticam, por exemplo, BDSM (bondage, disciplina, dominação e submissão). Se para a autora, a mídia digital aparece como central no processo de legitimar estilos de sexualidade estigmatizados nos limites e nas fronteiras do sexo, penso na pornografia do fetiche da podolatria masculina como produto midiático que pode conter um mecanismo de reiteração e subversão de discursos normativos sobre gênero e sexualidade, como destacam Paiva e Ratts (2016) diante da produção pornográfica. Afinal, a pornografia pode ser vista como uma escrita e/ou dispositivo cuja narrativa segue o princípio do prazer, a exemplo do que traz Maingueneau (2010). Ao lado do que aborda sobre "pornografia canônica", o autor traz que a expressão do discurso do sadomasoquismo ainda aparece mais marginalizado, devido a legitimidade de grupos seletos.

Portanto, procuro refletir sobre a pornografia através da cena-ação em contextos específicos de produção midiática online a partir de uma etnografia de tela, segundo o horizonte de Rial (2004) e os itinerários de gênero de Balestrin (2011), por meio de três vídeos nos sites 
estrangeiros My Friends Feet ${ }^{7}$, Str8 crushfeet $^{8}$ e Lads Feet ${ }^{9}$. Dessa forma, pretendo analisar como a mídia articula e desarticula a fixidez dos corpos pela construção do gênero masculino em determinados papeis sociais encenados como performance nos filmes que representam o desejo pelos pés masculinos. Mais do que espaço midiático, o pornô pelo excesso e extremo pode ir além do sexo e mostrar o caráter construído do corpo e do gênero a partir das imagens que formam a narrativa fílmica.

\section{A EROTIZAÇÃO DO PODER E A DESSEXUALIZAÇÃO DO PRAZER}

Diante das práticas dos prazeres, Foucault (1984) fala da variável do que pode ser chamado de "papel" ou "polaridade" através da relação do ponto de vista ético. De modo geral, o autor fala que se poderia chamar de "atores ativos" e "atores passivos" os sujeitos da atividade sexual e os parceiros-objetos figurantes no cenário dos prazeres, pois a relação com os desejos e a atividade sexual perpassa diferenciação e apreciação moral. O que é interessante na leitura do pensamento grego em Foucault (1984) é a forma como os temas da austeridade sexual não traduzem proibições, mas elaborações e estilizações de uma atividade que exerce o poder na medida em que pratica a própria liberdade. Afinal, "a relação com os desejos e com os prazeres é concebida como uma relação de batalha” (FOUCAULT, 1984, p. 63).

Diante disso, a singularidade história em que os gregos tinham prazeres com os rapazes consiste em uma laboração cultural, entre uma cogitação moral e um ascetismo filosófico. Portanto, o autor ressalta que em uma sociedade que admitia relações sexuais entre homens, há a difícil justaposição entre uma ética da superioridade viril e uma concepção de relação sexual pelo esquema da penetração na dominação do macho.

\footnotetext{
É sem dúvida a existência dessa dificuldade que explica, ao mesmo tempo, o silêncio no qual a relação entre os adultos foi efetivamente envolta, e a barulhenta desqualificação daqueles que justamente rompem com esse silêncio ao marcarem sua aceitação, ou melhor, sua preferência por esse papel "inferior". É igualmente em função dessa dificuldade que toda a atenção foi concentrada na relação entre homens e rapazes, posto que, nessa relação, um dos parceiros, por sua juventude e pelo fato de não ter ainda atingido um status viril, pode ser, por um tempo que se sabe breve, objeto aceitável de prazer (FOUCAULT, 1984, p. 193).
}

\footnotetext{
${ }^{7}$ Link de acesso ao site: < https://www.myfriendsfeet.com/>.

${ }^{8}$ Link de acesso ao site: $<\underline{\text { https: //www.clips4sale.com/studio/113562/str8crushfeet }}>$.

${ }^{9}$ Link de acesso ao site: $<$ https://www.ladsfeet.com/>.
} 
Desse modo, através dos usos dos prazeres, Foucault (1984) marca os modos de subjetivação dos tipos de sujeição, formas de elaboração de si e de teologia moral, sendo um dos quatro grandes eixos da experiência dentro dos temas da austeridade, a relação com os rapazes. Ao destacar o dispositivo da sexualidade, Foucault (1988) aborda as práticas discursivas e não discursivas que normatizam e controlam como regimes de verdade o corpo e o uso dos prazeres. Desse modo, a ideia institucionalizada de homossexualidade aparece produzida historicamente pelo dispositivo da sexualidade, principalmente, pela captura que visa dizer e ver sobre o sexo, na medida em que o pode adequar aos discursos nos regimes de verdade. Transferida da prática da sodomia para o que o autor traz como uma espécie de androgenia interior, hermafroditismo da alma, a homossexualidade apareceu como uma das figuras da sexualidade construída por uma série de discursos diante da psiquiatria, jurisprudência e literatura sobre espécies e subespécies no século XIX, o que de certa forma permitiu o avanço do controle social no sentido "perverso".

Assim, o homossexual do século XIX se torna o que Foucault (1988) chama de personagem, próximo de uma forma de vida entre a morfologia e a fisiologia tida como misteriosa, ainda que nada do que seja escape a sexualidade. "Ela está presente nele todo: subjacente a todas as suas condutas, já que ela é o princípio insidioso e infinitamente ativo das mesmas; inscrita sem pudor na sua face e no seu corpo já que é um segredo que se trai sempre” (FOUCAULT, 1988, p. 42). Como figura mista da aliança desviada a da sexualidade anormal, o jovem homossexual apareceu na perturbação do dispositivo da sexualidade para o dispositivo da aliança. Entre a afirmação e a liberação dos movimentos homossexuais, aparece a necessidade antes de tudo de superar a vontade de verdade que contorna o sexual imposta pelo dispositivo da sexualidade.

Diante disso, cabe destacar o que Foucault (1996) acredita que a reivindicação pela especificidade sexual deve se deslocar pelas formas de cultura e de discurso que não apenas se fixam no sexo. Afinal, o que faz o corpo social para o autor é a materialidade do poder que se exerce sobre os indivíduos, sobretudo, no investimento do corpo pelo poder e o trabalho do corpo através do poder como efeito. Ao lado da condução do desejo pelo corpo, emerge por outro lado a reivindicação do próprio corpo contra o poder e do prazer contra as normas morais da sexualidade, ainda que o poder se desloque e recue. Desse modo, para falar da construção discursiva do corpo, a exemplo da pornografia e da publicidade, o autor destaca como exemplo o autoerotismo no reflexo dos controles da masturbação que começaram na Europa durante o século XVIII. 
Através do pânico de que os jovens se masturbam, o medo se desdobra no corpo das crianças entre a instituição da família para objetificar a sexualidade e perseguir o prazer. Ao controlar e vigiar, a sexualidade também era produzida e intensificada como desejo de cada individuo pelo seu corpo. "A revolta do corpo sexual é o contra-efeito desta ofensiva" (FOUCAULT, 1996, p. 132). Desse modo, Foucault (1996) destaca na contra-ofensiva do corpo pelo enigma da revolta, o poder se articula na resposta da exploração do corpo pela erotização da economia e ideologia, mencionando produtos corporais e filmes pornográficos. Ao invés do controle-repressão, há o que o autor chama de controle-estímulo. Embora a masturbação tenha sido o segredo universal que ninguém comunica por ninguém, a figura do masturbador que aparece no fim do século XVIII tece o que Foucault (2001) traz na relação do monstro e do corrigível incorrigível.

Pelo dispositivo da sexualidade, a figura do masturbador apareceu e precisou de uma redistribuição dos poderes que investem no corpo dos indivíduos por meio de tecnologias de poder e instâncias de saber. É interessante perceber na reflexão de Foucault (2001) sobre a normalidade, a forma com que a masturbação tem relação em primeiro momento com o pecado contra a carne com o tato do do toque e em segundo momento com a vista do olhar que vigia e revela. "A partir desse momento, os corpos, os gestos, as atitudes, as caras, os traços da fisionomia, as camas, os lençóis, as manchas, tudo isso é posto sob vigilância" (FOUCAULT, 2001, p. 335).

No sentido de explicar a necessidade de uma arte de viver entre o movimento homossexual ao invés da busca por uma nova ciência da sexualidade, Foucault (2004) fala que a liberdade é criada e os desejos instauram novas formas de relações a partir dessas criações. Dessa forma, o sexo seria uma possibilidade de vida criativa na medida em que a experimentação não reafirma a identidade sexual, mas cria um modo de vida. É o que o autor quer dizer quando menciona que não devemos descobrir e reafirmar que somos homossexuais, mas criar modos de vida homossexuais pelas vivências da liberdade sexual, obras de arte, por assim dizer, que compreendam a sexualidade como processo que se inscreve na necessidade como efeito cultural.

Nesse sentido, Foucault (2004) acredita que as novas formas de vida e a cultura dessas relações devam atravessar as nuances sexuais, éticas e políticas na afirmação não da identidade, mas da força criativa entre as nossas criações culturais. A partir disso, o autor destaca que essas práticas em seu sentido de inovação possam não descobrir algo, mas criar novas possibilidades de prazer. É o exemplo que ele cita, ao mencionar Gayle Rubin, sobre o sadomasoquismo (S/M) enquanto subcultura capaz de inventar os prazeres através da erotização do corpo. Assim, a dessexualização do prazer aparece como o fundo da gaveta da criatividade que amplia a ideia de que o prazer sexual 
pode partir das partes do corpo, dos objetos utilizados e das situações vivenciadas. Como multiplicidade, o autor esquiva a construção tradicional do prazer ligada à tecnologia da carne e deriva para as criações elementares da cultura, pois não se cabe liberar o desejo, mas criar prazeres para que talvez surja o desejo por meio deles.

Diante disso, a identidade para Foucault (2004) é um jogo tecido a partir das relações. No que diz respeito à homossexualidade, ele destaca que ao invés de tornarmos a identidade um princípio da existência, como risco de retornar a forma ética da heterossexualidade tradicional, devemos estabelecer relações conosco mesmos a partir da diferenciação, criação e inovação. Através de uma luta, as relações de poder revelam situações uns com os outros e a resistência pela interioridade altera a dinâmica do jogo. "Pode-se dizer que o S/M é a erotização do poder, a erotização das relações estratégicas. O que me choca no S/M é a maneira como difere do poder social" (FOUCAULT, 2004, p. 270). Ao refletir sobre a prática, o autor fala que o jogo envolvido pelos prazeres enquanto relações estratégicas aparece de modo fluido, sobretudo, pelo fato de que os papeis podem ser invertidos na dinâmica da relação mestre-escravo. Entre acordos e regras, cabe pensar que o jogo não reproduz no interior da relação erótica a estrutura do poder, mas jogo estratégico que busca o prazer.

Assim, é interessante perceber que a prática do S/M cria o prazer entre identidades que se constituem enquanto acontecimento dessa criação. Para Foucault (2004), o S/M é uma utilização de uma relação estratégica que busca o prazer. Embora isso não seja algo novo, tendo em vista que na Idade Média a tradição do amor cortês do trovador enreda a estratégia dramática, o autor aponta que as relações estratégicas do S/M fazem parte do sexo como uma convenção no interior da relação. A partir disso, destaco uma reflexão importante de Foucault (2004) sobre as relações homossexuais pelo afeto fora dos quadros normativos que dialoga com a perspectiva da amizade pela disposição da liberdade. Depois da história da sexualidade, o autor enfatiza a necessidade de desenvolver a história da amizade, tendo em vista que do século XVI e XVII a amizade intensa desaparece no meio da sociedade masculina para se tornar outra coisa. Pelo entendimento de que a existência das relações sexuais entre homens tida como homossexualidade aparece como um problema a partir do século XIX, Foucault (2004) destaca o motivo da amizade ter desaparecido. Afinal, o que podem fazer dois homens juntos?

Assim, a sexualidade pode ser tida como experiência entre o que Foucault (2012) denomina pelos prazeres e pelas técnicas de si, sobretudo, nos três eixos que a constituem: a formação dos saberes, os sistemas de poder e a forma de reconhecimento como sujeito da sexualidade. A partir da análise da etnografia de tela dos vídeos pornográficos do fetiche da podolatria masculina on-line, 
penso com Foucault (2012) sobre o que ele traz como as práticas que fazem os indivíduos voltarem a si mesmos e procurem se decifrar como sujeitos de desejo a partir de uma relação consigo mesmos. Nesse sentido, destaco o que pode visto como o terceiro deslocamento para analisar os jogos de verdade na relação consigo mesmo e a constituição de si como sujeito. Entre as "artes da existência" como "técnicas de si", vale mencionar as subjetivações pela forma como as pessoas podem se determinarem e se transformarem. "Então, o corpo, na sua materialidade, na sua carne, seria como o produto de seus próprios fantasmas" (FOUCAULT, 2013, p. 14). Dessa forma, se Foucault (2013) fala que seria preciso ir à própria carne para refletir que o corpo retorna o seu poder utópico contra si, vale destacar que o corpo está sempre em outro lugar.

Diante disso, as heterotopias foucaultianas contornam o que Preciado (2010) traz sobre as "pornotopias" diante da relação entre o espaço, a sexualidade, o prazer e a tecnologia que produzem subjetividade sexual a partir das condicionantes da espacialidade, sobretudo, ao considerar a Playboy do diretor Hugh Hefner como uma oficina de produção arquitetônica multimídia, difusora de uma utopia sexual pós-doméstica e urbana na era da comunicação de massa. Assim, pela circulação de imagens pornográficas na internet, o autor destaca uma nova economia global diante das pornotopias multimídias por meio do comércio sexual. No caso do fetiche da podolatria masculina na pornografia online, entendo que a produção desse conteúdo também perpassa um novo regime de hipervisibilidade que tem como foco o corpo e a prática sexual para consumo generalizado. Entretanto, cabe destacar que os espaços virtuais substituíram a pornotopia Playboy e fazem do consumo do corpo o movimento de exposição de si.

Da corrida tecnológica da Guerra Fria, Preciado (2018) pontua como os lapsos da era farmacopornográfica aparece diante do gênero como construção produzida tecnicamente. Dentre dessa visão, os vídeos analisados fazem parte do que pode ser tido como forma de "pornificação do trabalho", ainda que faça dessas formas de auto experimentação uma deriva possível. É o caso como a pornografia pode fazer do motor do farmacopornismo uma cooperação masturbatória de excitação-frustação dentro da produção de subjetividade fetichista da podolatria, sobretudo, pela potência real ou virtual de excitação do corpo. Desse modo, enfatizo a capacidade da captura das formas de tecnologias de gênero pela variante do desejo cibernético e prostético pelo regime regulatório do corpo sexuado no prazer-fazer. Embora façam parte do processo de dessexualização do prazer, os dispositivos pornográficos parecem construir os gêneros masculinos na cena-ação pelos itinerários da podolatria como produção subjetiva virtualizada, não apenas performativamente, mas nas práticas que atravessam a materialidade dos mesmos por uma tecnossexualidade (PRECIADO, 2014). 
Assim, diante do que Butler (2019) traz sobre os atos performativos como formas de discurso, vale destacar o que aparece como os enunciados que ao serem ditos, não só realizam uma ação, mas exercem um poder de conexão. Dessa forma, se o poder do discurso produz o que nomeia, a performatividade pode ser tida por meio do poder atuado pelo eixo discursivo. "Assim, não há nenhum 'eu' que permaneça por trás do discurso e execute seu desejo ou sua vontade por meio do discurso" (BUTLER, 2019, p. 373, grifo da autora). No caso, se o ‘eu’ apenas surge ao ser chamado, compreendo que a cena-ação dos vídeos pornográficos analisados pode perpassar o modo como o reconhecimento social condiciona a formação dos sujeitos. Diante da performance de gênero nos enunciados performativos percorridos pela etnografia de tela, aponto a questão sobre a performance sexual que a autora entende pelas formas de "gênero" dentro da homossexualidade além das categorias "masculino" e "feminino".

É interessante perceber que Butler (2019) traz segundo uma lógica fetichista a partir da separação radical da sexualidade e do gênero, tendo em vista que ela considera ser inaceitável separar as formas de sexualidade dos efeitos das normas de gênero. Desse modo, a prática sexual e o gênero não são determinantes, ainda que dinâmicos e recíprocos. Assim, penso que as performatividades nos vídeos produzidas por meio do jogo de poder do fetiche podem borrar a linha imaginaria da matriz heterossexual, uma vez que as masculinidades na cena-ação podem oferecer para si mesmas uma variedade de locais de identificação. Dessa forma, "a performatividade descreve essa relação de estar implicado naquilo a que se opõe, essa virada de poder contra si mesmo para produzir modalidades alternativas de poder" (BUTLER, 2019, p. 398).

Pelos circuitos tecno-orgânicos, gêneros masculinos podem ser codificados pela construção simbólica e o seu efeito material, talvez essa produção pornográfica possa até possuir um bojo de imaginação das novas experiências estéticas, mas considero além desse campo midiatizado de construção do sexo-gênero pelo fetiche, a capacidade do regime de poder pornográfico suprimir o modo de vida desejante no seu próprio assujeitamento. Afinal, a pornografia aparece para Preciado (2018) como um dispositivo virtual masturbatório que espetaculariza a sexualidade. Nos limites da identidade, do corpo e do gênero, ressalto que os vídeos não escapam a ambivalência do poder, da técnica e do desejo, embora tenha um potencial subversivo do jogo entre os homens pode deslocar o ideal normativo, mas parece não o superar.

\section{A ERÓTICA DIGITAL DOS FLUIDOS, ENTRE O NOJO E O GROTESCO}


Para falar de como a produção pornográfica homoerótica percorreu o trajeto do começo do século XX e do século XXI, Reges (2004) relaciona as formas de produção, distribuição, divulgação e consumo. Dessa forma, o autor considera que a internet foi um dos campos mais importantes para a abrangência do segmento por meio de fotos, filmes e todo tipo de material vinculado à pornografia. De modo fácil, rápido e gratuito, ele compara a importância da entrada do videocassete e da tecnologia do VHS na década de 70. É interessante perceber que embora a análise de Reges (2004) se concentre nos anos 2000, vale perceber o quanto os filmes permanecem próximos do que ele traz sobre a internet e o pornô, sobretudo, na socialização homossexual.

Até porque os sites especializados na categoria do fetiche da podolatria trazem curtos filmes on-line, só com agora muitas vezes veiculados por meio de prévias gratuitas que podem ser vistas antes da compra ou da assinatura para possível associação à comunidade virtual; os internautas podólotras podem baixar o vídeo e ver on-line ao fazer o login no site através de registro com cobrança de taxa paga em dólar; e os projetos de design gráfico dos sites apesar de não serem tão elaborados, destacam os homens modelos mais famosos de cada plataforma e enfatizam a proposta de conteúdo pelo acesso. Diante dos aspectos destacados por Reges (2004) cabe abordar a questão da impessoalidade no acesso, o controle do material desejado e a possibilidade de manipulação, interação e criação de um arquivo pessoal de busca. No caso da podolatria masculina nos sites, é recorrente a produção de imagens e filmes amadores que criam o conteúdo na gravação de cenas que simulam o cotidiano pela câmera na mão em lugares comuns.

No que diz respeito ao sadomasoquismo no pornô homoerótico, Reges (2004) pontua que a metáfora do mestre e servo podem exemplificar a relação de hierarquização e dominação na maioria dos filmes. Assim, os filmes que privilegiam o sadomasoquismo aparecem, para o autor, delimitados pelo ciclo sexual entre o sexo oral, sexo anal e gozo. Pela corporalidade, pelas masculinidades e pelo homoerotismo, o corpo-pornográfico masculino aparece associado aos símbolos de virilidade e força, ainda que no conteúdo pornográfico de podolatria masculina dos sites analisados o foco no pênis grande não seja a premissa do desejo, talvez pelo protagonismo dos pés. Assim, ressalto que nos vídeos analisados a masculinidade hegemônica perpassa as ações e os contextos, tendo em vista que o controle-estímulo acontece pelo jogo discursivo de prazer entre as relações de poder.

Ao considerarmos a representação do corpo pela configuração artística do imaginário sobre o desejo, Medeiros (2008) explica a oscilação entre o erótico e o obsceno, a dissimulação e o explícito. Pela exploração das imagens do corpo masculino através dos pés na representação pornográfica, considero o que o autor traz sobre a imaginação para pensar a importância do olhar que deseja na construção social da sexualidade. $\mathrm{Na}$ medida em que o corpo pode ser tanto sujeito 
como objeto, encaro a pornografia como significado da "imagem do corpo que se expõe para provocar desejo de outro corpo" (MEDEIROS, 2008, p. 31). No paradoxo católico sobre o corpo, entre a representação e o corpo de santos e divindades, ora maldito e condenado, ora exaltado e cultuado, cabe pensar o fetiche da podolatria na adoração do pé, uma vez que se adorar significa devotar.

Entre mito e alegoria, Medeiros (2008) explica como as matérias tácteis da pintura e da escultura exige uma contemplação à distância pela proibição do toque, sendo a excitação visual a miríade do prazer que jamais se concretiza, como fetiche e sublimação. Ao transpor esse sentido para a internet por meio da exposição dos corpos através da imagem, o autor destaca que por mais que o sexo virtual se concretize, os corpos envolvidos no processo de subjetivação são interditados no exemplo do toque, dos odores e da transpiração. Na aproximação do sujeito desejante ao objeto desejado pelas técnicas de reprodutibilidade, a dessacralização do corpo sem a dessexualização do olhar perpassou da gravura à internet, só que na rede as publicações pornográficas remetem ao mitológico enquanto iconografia que categoriza o tráfego do obsceno. Afinal, o erótico aparece como forma de representação na escultura e na pintura, objetos únicos, enquanto o obsceno aparece na gravura e na fotografia, objetos reproduzíveis.

“Por isso, talvez seja mais pertinente não falarmos em 'fronteiras' entre o erótico e o obsceno, mas em margens líquidas, sujeitas a enchentes e vazantes” (MEDEIROS, 2008, p. 63). Dessa forma, penso diante do que Leite Júnior (2011) traz sobre a relação entre a pornografia e a estética do grotesco, principalmente, pelo material audiovisual pornográfico selecionado nos sites pornográficos possuírem pouca ou moderada influência dessa categoria estética específica na produção pela internet. Digo isso pela referência aos elementos sexuais do fetiche da podolatria masculina reproduzida pela forma como os pés aparecem idolatrados no toque, cheiro e gosto pelo reflexo do gozo, tendo em vista a agência de acessórios criados durante o acontecimento gravado da ação como tênis, meias, sapatos e chinelos.

Inclusive, como explica Maingueneau (2010) sobre o discurso pornográfico, as personagens aparecem cada vez mais próxima das pessoas comuns, nas quais as cenas em que os corpos exercem prazeres são espaços corriqueiros do cotidiano, os sujeitos desejantes focados na excitação por isso, geralmente e salvo os casos das representações dos dominadores na pornografia da podolatria masculina, os homens não utilizam sobrenomes. Como extradiscurso, os personagens muitas vezes não apresentam distinção por classe social, a ser na ordem intradiscursiva do desejo, entre dominador e dominado pelas posições dos papeis sociais. Dessa forma, as ações e os atos buscam o prazer e no caso do discurso pornográfico da podolatria destaco que o relato recria o mundo cotidiano dos navegadores, tendo em vista que no início dos vídeos os personagens descobrem 
suas capacidades de desejar, criadas durante aquele momento e encontradas na expressão máxima da potência erótica dos fluidos e das corporalidades masculinas.

Ao considerar o surgimento da pornografia na segunda metade do século XIX, Leite Júnior (2011) define a mesma como um produto que representa o obsceno padronizado, voltado para o consumo das massas, entre o prazer dos consumidores e o lucro dos produtores. "A pornografia é o discurso sobre sexo da cultura do espetáculo” (LEITE JÚNIOR, 2011, p. 12). Como discurso da cultura de massas sobre as práticas sexuais ligadas ao entretenimento, a pornografia nasce do sexo como distração. Da produção pré-pornográfica, nos séculos XVI ao XVIII com a base de Aretino e Sade, o autor destaca o que seria exagerar o já visto no teste de fronteiras, no jogo de limites entre os excessos e a transgressão. Da produção contemporânea, focada na primeira década do século XXI, o destaque da mídia digital borra fronteiras entre o erotismo e o obsceno pela quantidade de material e facilidade de acesso na grande vitrine de exposição.

$\mathrm{Na}$ estética da pornografia do fetiche da podolatria masculina, menciono a característica do close e dos detalhamentos na parte inferior e nos membros inferiores do corpo do homem, em especial os pés. No caso, os consumidores desse tipo de conteúdo audiovisual pela sublimação do detalhe devem alucinar na trama mínima do desejo, no excesso detalhado de quem observa com nitidez o despercebido dos movimentos do pé. É o que Leite Júnior (2011) traz a "alucinação do detalhe" como componente fundamental da produção pornográfica, sobretudo, na superexposição de determinadas partes do corpo. Para falar do que seria a estética do grotesco, o autor destaca que apenas no século XIX o grotesco se torna categoria estética que apresenta o sublime através do degradado em forma de utopia. O excesso como manifestação grotesca perpassa o gozo e as sensações por meio dos prazeres e do corpo, sobretudo, em relação inversa focada no excreto. Por isso, há o destaque na parte interior que se abre para a exterior, pela boca e narina.

Desse modo, se um dos elementos fundamentais das estéticas grotescas é o rebaixamento, dos excrementos e do baixo corporal, destaco a forma como a pornografia do fetiche da podolatria masculina apresenta os corpos dos homens na sobreposição das imagens no excesso dos pés. Talvez, como desdobramento do desenvolvimento da década de 1990 na indústria pornográfica estadunidense e da mudança significativa no pornô no século atual, focada na ação mais selvagem, os filmes de podolatria masculina tenham sido resultado desse encadeamento do grotesco. "É então justamente sob a estética do grotesco que pode ser entendida a pornografia em geral e, especialmente, a conhecida como bizarra/ fetichista/ sadomasoquista" (LEITE JÚNIOR, 2011, p. 18). No caso, cabe relacionar o que o autor traz pelas imagens de humilhação e práticas com excrementos com o fetiche da pornografia etnografada pela tela, apresentando uma estética hiperbólica para o repulsivo. 
À vista disso, o autor aborda que a pornografia digital ampliou a disseminação de conteúdo e intensificou as características do grotesco. No caso da pornografia de fetiche da podolatria, o traço da distinção se dá na dominação do performer focada na boca que lambe, cheira ou toca nos pés do dominador. Pelo fato de enfatizar a parte inferior do corpo, o desejo está constantemente ligado à sujeira, ao mau cheiro e à excreção do suor, proporcionando prazer pelo prazer no jogo constante de poder. É importante destacar que o belo está associado mais ao pé do que ao rosto do homem na pornografia do fetiche. De certa forma, as reproduções do fetiche da podolatria masculina na pornografia online está aparentemente associada ao sentido do maltrato pelo gosto da humilhação como vetor de prazer no gozo.

Assim, os homens que dominam os outros parecem fazer do exercício performativo da estimulação agressiva uma forma de usar os prazeres pelos pés como principal parte do corpo envolvida no prazer. Como resultado visual, os rostos acabam deformados pela força do pé, por vezes, associada ao esmagamento e as línguas terminam sujas de limparem os pés. Pelo fato de serem muitas vezes vendidos pelas plataformas próprias de produtoras ou pelos próprios consumidores e/ou vendedores do produto independente, a circulação comercial pode estar ligada ao que Leite Júnior (2011) traz como impacto causado no espectador, tendo em vista que o autor menciona a podolatria como fetiche da estética do grotesco e define como adoração as práticas sexuais envolvendo pés. Pela análise do material audiovisual selecionado, destaco que "o prazer de colocar em cena aquilo que se pressupõe que estivesse 'fora de cena" (LEITE JÚNIOR, 2011, p. 21).

Nesse sentido, destaco o nível estético e performático do que Diaz-Benítez (2013) traz na percepção da pornografia pela construção das imagens e pela elaboração dos discursos entre a normatividade e a transgressão por meio dos enunciados de gênero e sexualidade. Através da exposição dos corpos e das práticas e a exploração das situações extremas, o valor estético do show pornográfico aparece construído entre o exagero e o realismo. "El porno es elaborado como un show, siendo justamente lo espectacular aquello que constituye su base"10 (DIÁZ-BENÍTEZ, 2013, p. 95). Dessa forma, está na performance a valorização das imagens que expressam o discurso pornográfico, por isso gostar do sexo é a principal ferramenta do performer no prazer de se exibir. A autora pontua que o talento está na própria performance, sobretudo, pela valorização da estética do realismo e até do hiper-realismo.

Diante disso, a partir do que Diáz-Benítez (2013) traz como a técnica da projeção das imagens nos pornôs de criarem a sensação de presença pela situação narrada, destaco que a

10 “O pornô é preparado como um show, sendo o espetacular justamente o que constitui sua base" (Tradução nossa). 
podolatria masculina procura pela situação encenada e pelo contexto abordado produzir o desejo pela subjetivação de estar entre as texturas, os cheiros e as temperaturas dos corpos masculinos. Embora não seja focada no ato sexual em si, a gravação dos vídeos parece obedecer a um estilo ritualizado de praticar o fetiche por meio de um esquema que privilegia mais o estímulo do que controle, em uma possível sobreposição de um sobre o outro e vice-versa.

Assim, procuro no que Diáz-Benítez (2015) destaca como espetáculo da humilhação, pelos tensores libidinais da violência, associar a relação dos vídeos analisados com o segmento do mercado do fetiche que reúne o pornô de humilhação. Ao mencionar que alguns sites remetem a estéticas que são conhecidas no pornô na alusão mais direta ao BDSM, a autora enfatiza que na produção do fetiche hoje é possível perceber uma vasta associação à adoração de uma parte do corpo, especialmente dos pés. O pé aparece como fio condutor das práticas que mobilizam o prazer e envolvem a relação no domínio com violência, ele pisa, bate e/ou relaxa, ocupando o centro das atenções nos atos do escravo que beija, lambe e acaricia seu próprio rosto, ou seja, devota às atenções do dominador.

Nessa humilhação, prazer e perigo convergem na abertura do prazer. Apesar do meu foco ser na podolatria masculina, as cenas coincidem muito com as que Díaz-Benítez (2015) descreve quando destaca que possivelmente na dominação o escravo fica de joelhos enquanto o dominador em pé chuta o rosto ou alguma outra parte do corpo. Porém, os vídeos analisados de um dos sites são comuns cenas em que o dominador está sentado ou deitado enquanto o escravo o serve de modo forçado ou não. A mudança ocorre de acordo com a intensidade e o desejo, pela humilhação excessiva no próprio desejo de servir ao mestre como liberdade do escravo. É o que a autora traz pela "submissão voluntária” que nem sempre envolve o ato da penetração. "Quer dizer, não há humilhação se ela não parecer real, e esse parecer real começa a ser construído na minúcia” (DIÁZBENÍTEZ, 2015, p. 70).

Nesse sentido, entendo também que pelas estéticas e performances envolvidas na pornografia da podolatria masculina, o contrato do realismo aparece estabelecido entre o produtor e o consumidor que procura na encenação do dominador com o escravo a configuração do desejo pelo fetiche. Por isso, percebo que mais real do que a encenação entre diálogos e situações é a construção da cena pela forma como o pé aparece. O consumidor deseja a materialidade do pé real pela veracidade do olhar nos simulacros da imagem virtual. Afinal, pelas situações com os modelos que simulam atividades físicas ou profissionais envolvendo o fetiche pela encenação cotidiana, o pé limpo, sujo, suado e/ou com chulé em sandálias, sapatos ou tênis diferenciam o enredo da gravação pela relação estabelecida no prazer. 
Pelos cenários sadomasoquistas, Gregori (2015) destaca as expressões do mercado erótico contemporâneo pelas práticas e pelos processos sociais diante nas normatividades sexuais. É interessante destacar que embora os jogos de poder disponham de diversas posições, nas representações do fetiche da podolatria masculina, uma forca dramática parecer partir de um repertório de convenções culturais e sociais disponíveis pelas assimetrias materializadas entre os corpos e o poder que normatizam o gênero. Assim, entre as cenas e os cenários dos desejos masculinos, vale refletir sobre as relações entre violência, gênero e erotismo pelo modo como a convenção atravessa os enredos pelas práticas e problematizar as manifestações homossexuais que constituem os limites entre os modelos de naturalidade e normalidade, pelo comando e pela submissão.

Portanto, vale dizer que a corporalidade e os fluidos corporais masculinos são elementos significativos na performance da adoração encenada nos filmes analisados. É o que Barreto (2019) analisa a partir da erótica da fragmentação corporal masculina no contexto das práticas para homens, sendo importante o que ele traz diante dos produtos corporais tais como excreções e fluidos a construção da economia libidinal e do gênero, pelo risco e desejo e pela repulsa e excitação. Não fica de fora nos vídeos o que o autor traz pelo princípio da masculinidade que performa pelo exagero o desejo entre normas, valores e roteiros. Diante disso, o corpo-fragmento do homem e o produto podem ser vistos na pornografia do fetiche da podolatria masculina pelos sentidos do pé e do suor, dada a elaboração do corpo masculino durante o exercício performativo da encenação.

“A erótica está associada, dessa forma, à produção de certos fluidos que se generificam e têm o poder de generificar (no caso, masculinizar) em sua produção, troca e consumo" (BARRETO, 2019, p. 724). No caso, os suores como elemento condicionante do chulé nos pés aparecem dramatrizado diante das cenas de dominação ou humilhação, pois são fluidos que incitam cheiros pelos sentidos que valorizam os corpos masculinos. Se essa relação da masculinidade com as substâncias gera o que o autor aponta como "arte", pela apreciação de tamanhos, formas, gostos, sabores, cheiros e texturas, ou seja, um conhecimento próprio por meio dos elementos corporais, no caso da podolatria masculina, acredito que entre nojo e prazer o pé é a parte do corpo que produz o rebaixamento e a lógica do poder no gozo pelo ato de servir. Isso se relaciona com o que Diáz-Benítez (2015) aborda pelas eróticas do nojo pelo caráter disruptivo da produção da humilhação.

Assim, pés grandes, sujos, suados e com chulé parecem conduzir a encenação em uma intensidade maior, tendo em que vista que "é importante apontar como a 'sujeira' também faz parte de uma certa 'cosmética ou estética da dissidência', na qual essa "contravenção" de valores de 
contenção e higiene contribui para a composição de uma cena de alto potencial erótico" (BARRETO, 2019, p. 728). Nesse sentido, a masculinidade enaltecida e produzida entre as relações masculinas encenadas pela pornografia do fetiche da podolatria beira, a groso modo, na sorte de servir ao macho pela convocação do desejo de ser inferior na condição do prazer, ou seja, na fissura de uma encenação do cotidiano. A subjetivação do desejo encontra o potencial do gozo, embaixo dos pés de um homem pelo cheiro e pela textura que aquele momento vivido afeta a libido em uma economia de troca que marca a diferença. Dessa forma, vale destacar que "na navegação em sites pornográficos, as janelas extras, as frases tremeluzentes e, por vezes, os desenhos, são utilizados com o intuito de envolver os sentidos e tornar a navegação tão vibrátil, quanto esses elementos se apresentam” (VIANA, 2014, p. 140).

\section{ETNOGRAFIA DE TELA: A VIRTUALIDADE DOS PÉS NA NARRATIVA PORNOGRÁFICA ONLINE}

Ao me aproximar do horizonte metodológico da etnografia de tela, percebo o que Rial (2004) assinalada como sensibilidade na pesquisa em realizar uma etnografia sem precisar de muitos números pela especificidade do contexto mais amplo a ser destacado. Assim, considero a prática da etnografia pelas imagens em movimento e pela articulação com os estudos de gênero e sexualidade, sobretudo, na relação da mídia com a nuance antropológica visual imersiva sobre a tela. Desse modo, faço da observação sistemática e do registro em caderno de campo, com ênfase no que a autora destaca pela escolha das cenas mais aprofundadas pelas personagens e pelo enredo e do período de contato com o campo e os filmes. Como explicam Balestrin e Soares (2012), é preciso analisar o filme dentro de um contexto sociocultural, a partir da forma como está sendo vista e do que ela causa.

Dessa forma, analiso os movimentos da câmera, os planos, a construção dos cenários, o papel dos personagens, os diálogos envolvidos e os elementos estéticos que compõe a visualidade dos filmes escolhidos dentro dos sites pornográficos. De acordo com Rial (2004), a etnografia de tela permite a capacidade de revelar espaços sociais através do audiovisual pela reflexividade. Assim, considero como a produção midiática a ser investigada por meio dos três sites de conteúdo pornográfico online: My Friends Feet, Str8crushfeet e Ladsfeet. Cada site possui uma produção de conteúdo audiovisual padronizada que pretende alcançar os sentidos específicos a partir de intensidades diferentes no endereçamento do público consumidor, por isso a escolha de apenas 
um vídeo para cada plataforma. Assim, destaco o que Travancas (2013) traz pelo elemento importante no processo da etnografia da comunicação, a subjetividade do pesquisador em interpretar o que vê e sente.

No primeiro, pretendo mostrar o ritual do desejo no ciclo do prazer da encenação na performance da adoração pela reprodução pornográfica online; no segundo, viso articular as formas com que o fetiche pode romper com a encenação em busca da criação de uma hiperrealidade; no terceiro, procuro apontar o contexto em que a erótica dos fluidos corporais enaltecidos na visualidade pornografia pode criar próteses reais para a adoração individual. Assim, com esta etnografia de tela reflito sobre as três dimensões narrativas diferentes de modo sucedido para compreender as nuances de gênero e sexualidade nas estéticas do grotesco e eróticas do nojo da podolatria masculina em rede.

Nos três sites, os movimentos são polarizados nos eixos de dominação e de submissão entre os jogos de poder que incitam o desejo. Geralmente, um dominador pede e um dominado obedece, de modo forçado ou não, o desejo conduz o fio da dominação em que o relaxamento, descanso e gozo que aparecem na sentido do rito da performance da adoração: do toque, do cheiro e do gosto na sequência de pegar o pé, sentir o chulé e depois o gosto da pele. De modo direto ou indireto, a evidência do rebaixamento é um dos tensores libidinais na performance da adoração, de cima para baixo, da ordem à obediência pela espontânea vontade diante dos vários modos de desejar. A montagem do vídeo constrói cenas, em sua maioria estáticas e pouco dinâmicas, de servidão pelo ato de desejar.

$\mathrm{Na}$ maioria das vezes sem trilha sonora, os personagens são apresentados através de diálogos muitos curtos ou nenhuma conversa, mas cada palavra incita o desejo nas entrelinhas do olhar pelas situações cotidianas e pelos lugares comuns. O contexto em que o fetiche aparece praticado durante a encenação potencializa a dimensão erótica, tendo em vista que a situação procura recriar a atmosfera do fetiche pelo sensorial do cotidiano no uso dos prazeres pelo corpo. Os homens estão quase sempre de calçados fechados, sejam de tênis ou sapatos, com meias brancas e/ou pretas que no caso da primeira podem aparecer intencionalmente mais sujas, recém utilizadas em alguma atividade profissional e/ou pessoal que tenha demandado esforço físico. Afinal, a excreção corporal masculina pela transpiração no suor e chulé aparece como um produto enaltecido.

Como vestimenta dos homens, as roupas dos dominadores são em sua maioria roupas esportivas ou profissionais, a exemplo do traje utilizado na academia com ênfase no tênis e do terno utilizado no trabalho com ênfase no sapato social, que criam uma ambiência relativa à prática 
de esforço que excreta o suor pelos cheiros e pelas texturas do desejo. Entre o tato e o paladar, penso que embora a visualidade dos vídeos aguce o sentido da visão na tessitura da narrativa, o tato e o paladar dos personagens encorpam o espectador para dentro da tela e colocam eles no enredo da situação. Talvez, por isso a montagem foque em quem está sendo adorado na performance e não em quem adora. A narrativa deve parecer improvisada, na qual minuciosamente o prazer como construção subjetiva atravessa o social e enreda na visualidade a sensação do ato.

\section{1. “MY FRIENDS FEET": DIMENSÃO COREOGRÁFICA, ENCENAÇÃO PORNOGRÁFICA}

O site My Friends Feet está na rede desde 15 de fevereiro de 2000. Ao digitar o endereço no navegador, o redirecionamento conduz até uma prévia do site que anuncia um aviso de restrição de idade para acesso. "Qualquer pessoa com menos de 18 anos NÃO deve entrar neste site. Da mesma forma, você não deve entrar neste site se os sites adultos violarem os padrões legais ou da comunidade em sua localização geográfica atual”, destaca o conteúdo impróprio com um plano de fundo com duas fotografias dos modelos Pheonix e Pablo, ambos sentados só que o primeiro aparece descalço e o segundo com roupas profissionais de executivo. Em seguida, o site destaca que "todos os modelos de pés masculinos têm mais de 18 anos e todas essas informações estão arquivadas. Todos os modelos masculinos de pés, meias e cócegas tinham pelo menos 18 anos quando foram fotografados". Apenas abaixo, em tamanho de fonte menor, a cidade da produtora da cidade de Wilmington no estado norte-americano do Delaware, no condado de New Castle.

No primeiro vídeo analisado do My Friends Feet, o modelo Ace Era chega com roupas esportivas, uma regata branca, um short preto e um tênis sneaker cano curto, entra em uma pequena sala com luz branca e se senta no sofá-cama que está próximo ao criado-mudo do cenário. Ele vem como quem praticou atividade física e demonstra cansaço, isso aparece pela forma como o modelo suspira, torce o pescoço e aprecia o cheiro das suas próprias axilas. Ace levanta os braços pra cima e estica as pernas como quem se espreguiça e relaxa os músculos, os pelos na sua axila podem ressaltar a intenção visual de remeter à virilidade e aos produtos eróticos pelos fluidos masculinos na encenação do vídeo.

Após tocar o seu tórax, o modelo, na posição evidente que ressalta o seu nome pela construção do personagem através de cada performance de dominador, chama o ator dominado pelo pronome de "boy". Na situação narrada pelo breve diálogo, o modelo dominador está atrasado 
e não é a primeira vez que isso acontece, assim ele ordena que o trabalho da adoração seja feito como forma de relaxamento, pois chegou da academia e quer que o ator dominado faça o trabalho melhor do que da outra vez. No plano médio, lado do ângulo frontal, pelo fato do corte pegar a posição central do modelo na narrativa e apontar a movimentação dele no enquadramento, a câmera está a uma pequena distância média do modelo que ocupa parte quase que total do ambiente, ainda que o cenário seja visto a sua volta.

Assim, iniciam os primeiros minutos do que chamo de performance da adoração no fetiche da podolatria através das corporalidades na pornografia masculina online. $\mathrm{O}$ ator dominado tira os tênis de Ace e cheira, só que no vídeo o modelo mesmo assim pede pra ele colocar o seu nariz novamente no tênis e cheirar com mais intensidade. A cada frase dita pelo ator dominado, ele termina com a expressão de obediência, "sim, senhor", enquanto o dominador ordena apontando o que deve ser feito na medida em que diz como deve ser feito. Quando o dominado cheira profundamente o outro par do tênis, Ace diz “aqui vamos nós”, começa a tocar o seu pênis e xinga o servo. As meias brancas de Ace estão evidentemente sujas, após o dominado começar a cheirar a meia que veste o pé direito e fazer uma massagem, o modelo relaxa e ordena que ele coloque a boca. Ele cheira e suspira, Ace pede pra ele aproveitar e fazer o seu trabalho. O dominado demonstra voracidade no ato de servir, lambe as meias do modelo e parece alucinar na falta de controle diante da oportunidade de cumprir o seu papel como um trabalho feito com prazer.

Figura 3 - Recorte da primeira cena analisada no vídeo do My Friends Feet.

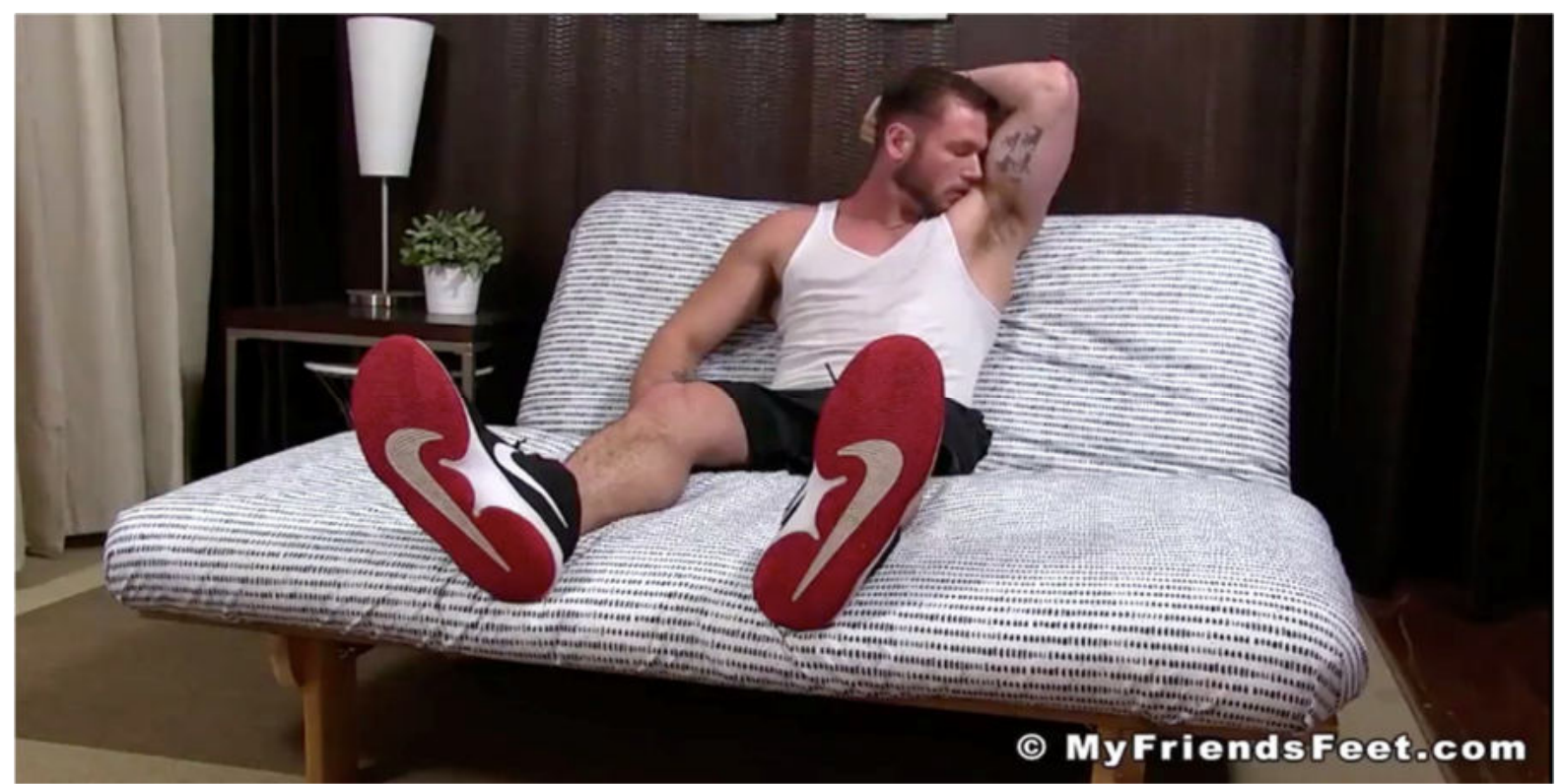

Fonte: My Friends Feet (2017). 
Ace utiliza do pé esquerdo para esmagar o rosto do dominado enquanto ele está lambendo o pé direito, entre os dedos e a sola do pé. Ace afirma que o dominado é um garoto de sorte. Após três minutos, há um corte no vídeo em que o modelo já aparece sem camisa e ordena que o dominado retire suas meias. Quando retira a meia do pé direito, o dominado coloca toda a meia dentro da boca, mas além disso Ace pede que enquanto sente o real prazer na situação, entre a massagem relaxante e a adoração dominante, ele se deleite mais ainda. Do plano médio, da cena anterior antes do corte, a câmera foca agora no plano fechado, lado do ângulo 3x4, entre metade dos pés do modelo e metade do rosto do ator, para ressaltar a intensidade do desejo do dominado em engolir a meia de Ace e cheirar os seus dedos dos pés. A gravação privilegia o plano fechado de intimidade e expressão, sem deixar espaço do ambiente à vista, o prazer ocupa todo o cenário pela câmera próxima ao dominado. O rosto se desdobra em seus pés.

Figura 4 - Recorte da segunda cena analisada no vídeo do My Friends Feet.

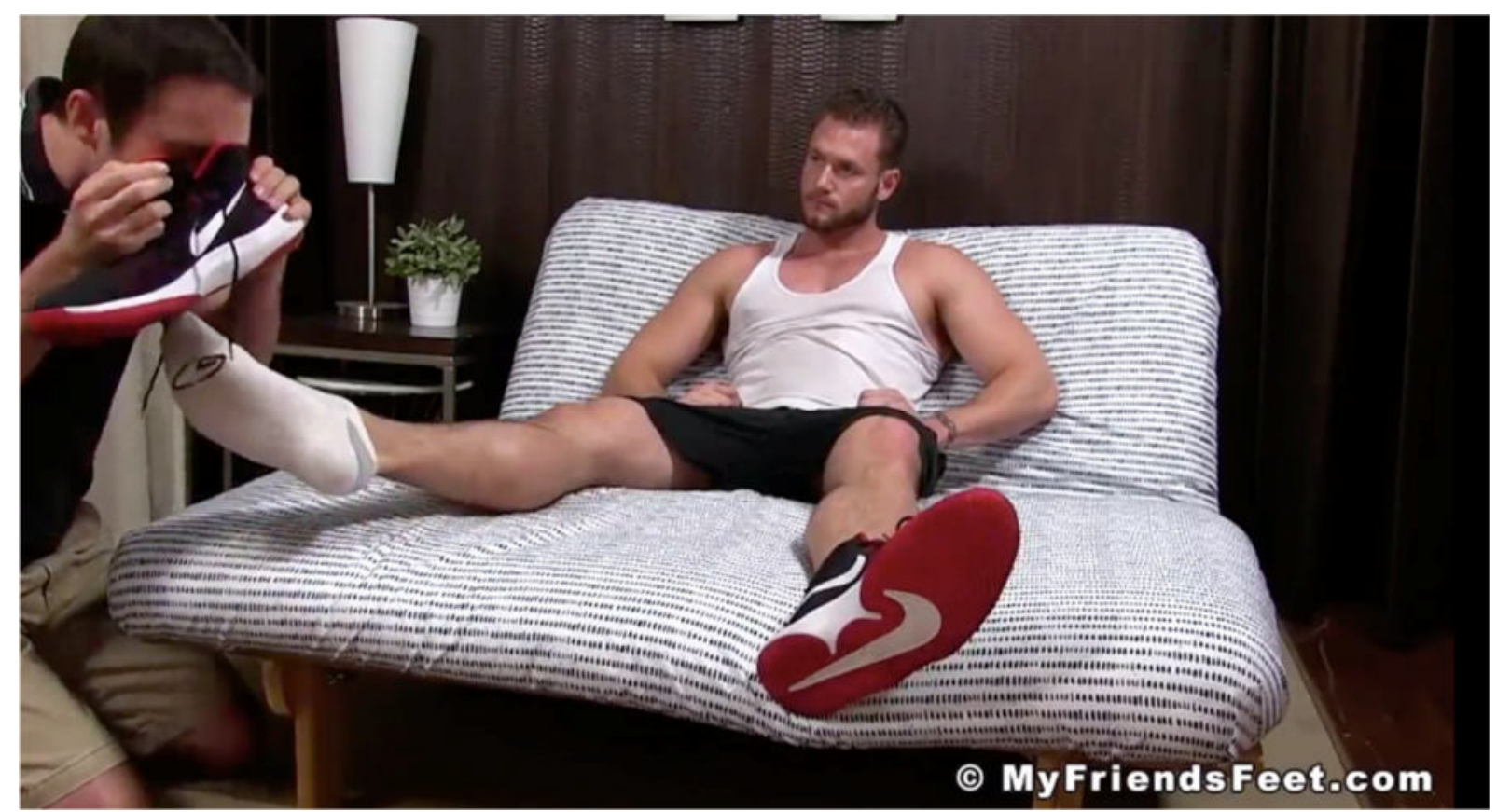

Fonte: My Friends Feet (2017).

No vídeo, toda ação executada pelo dominado é uma ordem do dominador. Ace ordena que o dominado tire as meias da boca, cheire novamente e abra as suas calças e coloque elas dentro da cueca. De volta ao plano médio, o dominado continua a adoração lambendo os pés descalços do dominador. O enquadramento privilegia o corpo inteiro de Ace enquanto fragmenta o dominado pela cabeça no ato da adoração. O plano fechado apenas retoma nos momentos em que o foco está na língua e nos dedos, quando o dominado lambe entre os dedos do modelo e cheira o 
pé. Ace toca o seu pênis e pede pra que o dominado tire o seu short, mas antes pede que ele relembre que o dele deve ser tirado primeiro. O modelo começa a se masturbar depois de pegar com as mãos um pouco de saliva da sua boca para lubrificar o ato, a saliva do dominado escorrega pelos pés do dominador.

No plano fechado, com o sentido de contra-mergulho, a câmera um pouco mais abaixo do nível dos olhos condiciona uma experiência de mergulho pela situação de rebaixamento do dominado que, por vezes, cobre o rosto de Ace quando lambe os seus pés e deixa visível as mãos de Ace se masturbando. Aqui a fragmentação da cena ocorre pela sobreposição do dominado diante do dominador, do desejo pelo fio condutor da ordem do gozo. Através da simulação da felação no chão, o dominado encena o sexo oral no dedão do pé de Ace que se também se masturba em cima do sofá-cama. A cena mostra outro corte no último minuto do vídeo, no plano geral com lado superior, o ator e o modelo aparecem ambos fragmentados, só que Ace da cintura para baixo com foco nas pernas e nos pés e o dominado da cintura para cima com foco na cabeça e no tórax. No final do vídeo, há um encadeamento entre o primeiríssimo plano e os planos médio e detalhe que enfatizam o prazer do dominado no reflexo do gozo de Ace, com foco na língua, nos dedos do pé e na boca, que ejacula pela adoração do dominado e pelo ato de se masturbar. $O$ filme termina quando o modelo ejacula.

Figura 5 - Recorte da terceira cena analisada no vídeo do My Friends Feet.

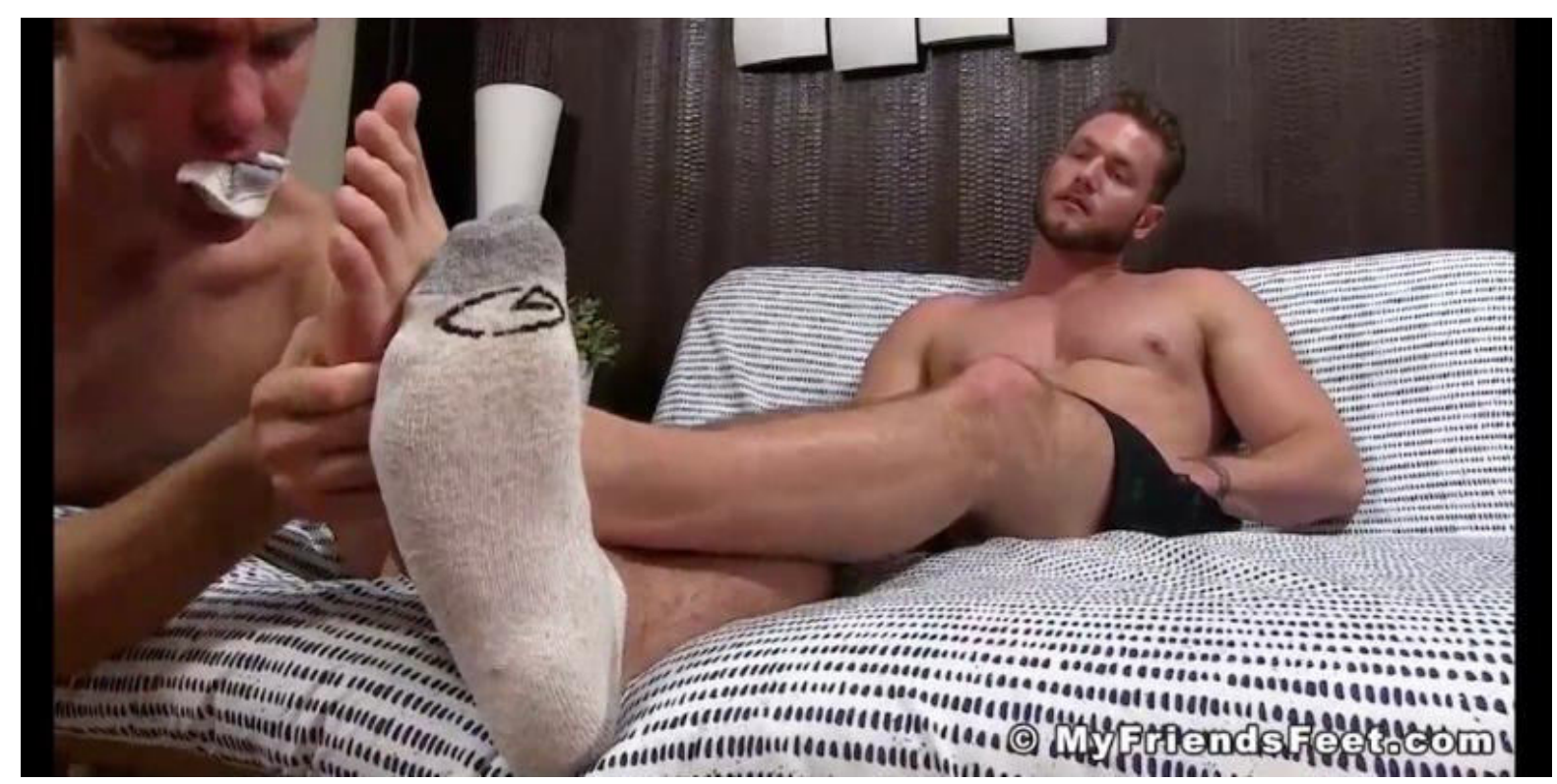

Fonte: My Friends Feet (2017).

\section{2. “STR8CRUSHFEET”: DIMENSÃO CONFESSIONAL, HIPER-REALIDADES DO DESEJO}

Cadernos Cajuína, V. 6, N. 1, 2021, p. 213-244. 
O segundo vídeo analisado foi produzido pela Str8crushfeet que disponibiliza seus vídeos à venda no site Clips4sale, plataforma para maiores de 18 anos que possui mais de 7 milhões de videoclipe de fetiche e pornografia amadora para adultos premiadas pela AVN Awards Show, Free Speech Coalition (FSC), XBIZ, VENUS, FETISH CON. Os conteúdos fornecidos pelo site são destinados para uso pessoal e não comercial dos utilizados. Todos os modelos são maiores de 18 anos. Talvez por isso, os vídeos produzidos no Chile pela Str8crushfeet busquem um aspecto mais amador dentro da sua produção padrão, inclusive dentro da categoria " male feet" " utilizada do site para endereçamento ao público são utilizadas outras categorias relacionadas como "gay foot worship" "12 "reality porn" ${ }^{13}$ e "sock smelling" 14 . O vídeo que foi colocado à venda no dia 26 de fevereiro de 2020 em formato MP4 aparece com etiqueta de preço por $\$ 18,99$ US e duração de 98 minutos.

No sentido de criar o hiper-realidade pelo caráter amador e fetichista da produção, os vídeos da produtora apresentam uma grande descrição textual de como o ator/gravador do vídeo experenciou o fetiche, na locução própria e no formato câmera na mão, como forma de vender o produto através das sensações. É interessante perceber como a Str8crushfeet se diferencia um pouco do My Friends Feet, chegando a uma divulgação das experiências de modo mais restrito, tanto pela hospedagem dos vídeos em um site de venda ao invés de um canal próprio de propaganda e venda pornográfica online, como pelos planos e pela abordagem estética e performática da situação e dos contextos.

Dessa forma, na descrição deste vídeo analisado, há o testemunho da experiência com cada ator envolvido na gravação. Assim, não irei chamar de encenação, pois embora se aproxime disso, rompe muito com o formato da pornografia do fetiche da podolatria, muitas vezes ainda coreografada no script padronizado do fluxo do desejo entre dominador e dominado. Até porque os vídeos do Str8crushfeet parecem transformar o dominador no instante improvisado da gravação pelo desejo de última hora, sentido pela situação do cotidiano e pelo contexto fetichizado. O título longo do vídeo inclusive mostra como a gravação parece ser o making off na testagem de modelos pela experiência de um fetichista que grava e compartilha seus desejos em rede: "pés heterossexuais da rua caça XI: limpando dedos suados e salgados de skatistas com a língua, encontrando uma das novas estrelas principais do str8crush de 2020 ".

\footnotetext{
${ }^{11} \mathrm{Na}$ tradução do inglês, a expressão etiquetada significa pés masculinos.

${ }^{12} \mathrm{Na}$ tradução do inglês, a palavra retoma ao fetiche na adoração de pés gays.

${ }^{13} \mathrm{Na}$ tradução do inglês, a expressão identifica no site a categoria de pornô realista.

${ }^{14} \mathrm{Na}$ tradução do inglês, a expressão pode ser lida como cheirando meias.
} 
Figura 6 - Recorte da primeira cena analisada no vídeo do Str8CrushFeet.

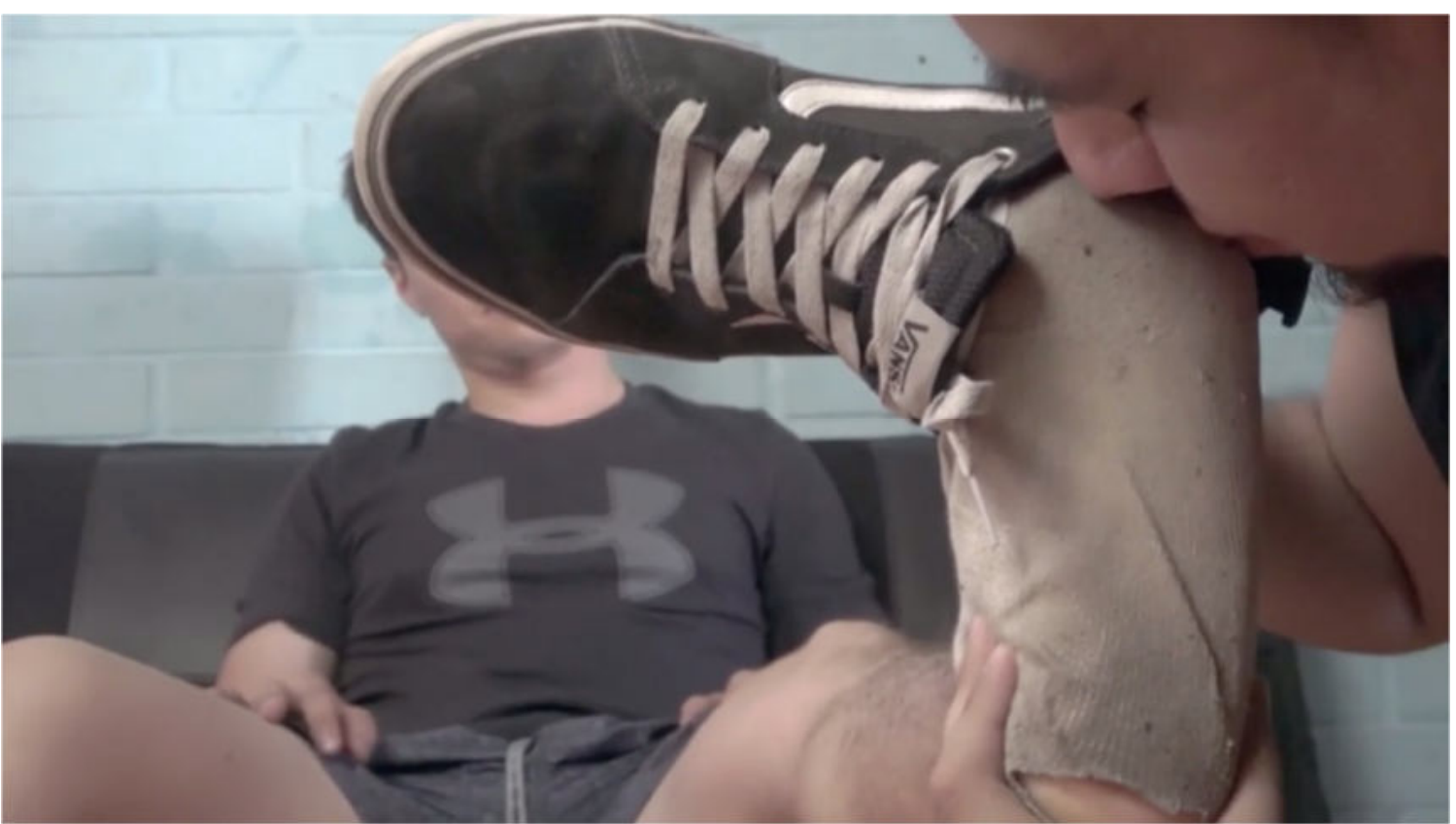

Fonte: Str8CrushFeet (2020).

Figura 7 - Recorte da segunda cena analisada no vídeo do Str8CrushFeet.

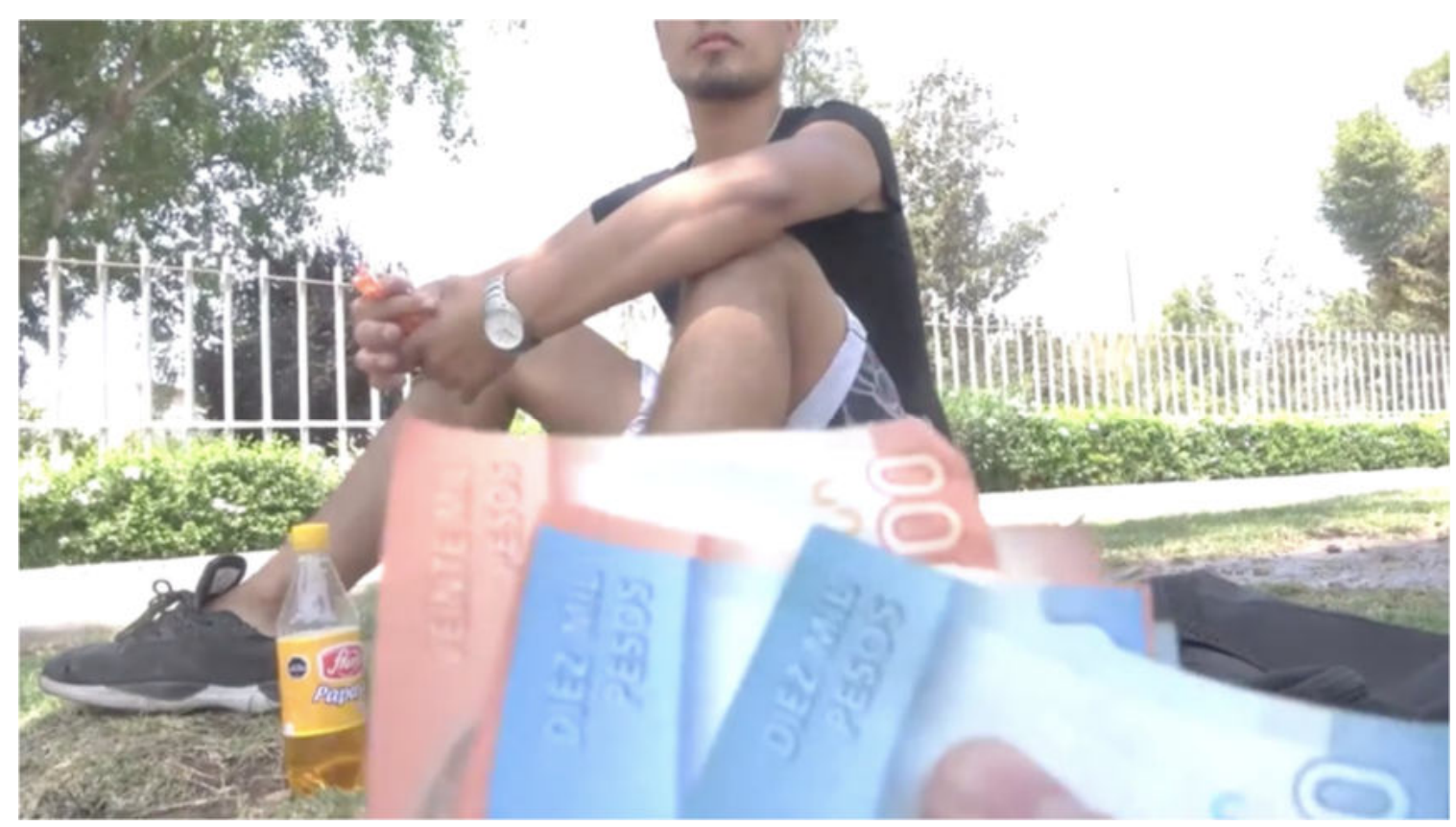

Fonte: Str8CrushFeet (2020).

$\mathrm{Na}$ descrição, a produtora remete à densidade de sensações e intensidade de desejos pela personalidade dos atores envolvidos na gravação, compondo a cena "hiper-real". No caso, os skatistas e ciclistas são descritos como joias divinas para fetichistas de pés. "Fui a outro ponto de skatista na cidade, conheci Mathew uma das mais belas coincidências da vida, por que digo coincidência, se todos os meninos da rua são pegos ao acaso? Bem, eu sinto que Mathew foi 
colocado lá pelo destino", fala quase de modo confessional como quem escreve em um diário os desejos e disponibiliza em gravações. "Mathew concorda em botar os pés na minha cara por dinheiro, ele me diz que está com um amigo ciclista e que o convenceria a ir para minha casa junto com ele". Embora o vídeo procure retratar a realidade ao máximo, a descrição textual dispara sensações que talvez apenas o visual ou audiovisual não consiga instigar. No final da descrição, o produtor diz que depois de novas gravações com um dos jovens, já sabe qual será a nova estrela do Str8crushfeet deste ano por afirmar que Mattew literalmente parece um Deus e os seus pés são como um céu na terra.

O vídeo começa a ser gravado no formato câmera e na locução do produtor que confessa o amor por skatistas e projeta o fetiche naquela cena dos jovens praticando esportes. Depois de observar alguns deles, ele aborda o skatista e pergunta a idade de cada jovem e o que esperam do futuro. Assim, sem tantas delongas, apresenta a proposta de gravar um vídeo para o seu blog mostrando os pés. A situação gera um pouco de desconforto e assusta os jovens que estavam apenas se divertindo com os skates e as bicicletas. De modo direto, logo pergunta se eles aceitam dinheiro para chupar os seus pés por $\$ 80$ mil CLP pesos chilenos. Um dos meninos diz que o seu pé está muito suado e não sabe se alguém iria querer chupá-lo por conta disso, mostrando as meias sujas na praça de skate. O produtor rebate e pede para que ele não se sinta mal por esse comentário, pois ama pés assim.

De modo parecido, a adoração segue o mesmo fluxo do rito coreografado pela My Friends Feet pela projeção do modelo Ace Era, só que atribui papeis no improviso e, por esse motivo, desponta pelo caráter amador na construção que simula o hiper-real, onde as eróticas do nojo partem das estéticas do grotesco no próprio cotidiano. Só que nos aspectos que enaltecem os produtos masculinos das excreções corporais, o vídeo ganha endosso por não operar pela encenação dos cortes trabalhados na edição pornográfica e no script pornô, mas pela gravação quase bruta do material. Assim, as meias brancas sujas, os tênis velhos, o suor no corpo e a atividade desempenhada antes da adoração pelos atores que não são modelos, mas simplesmente jovens comuns que contextualizam o fetiche, podem situar o desejo de modo mais intenso.

Figura 8 - Recorte da terceira cena analisada no vídeo do Str8CrushFeet. 


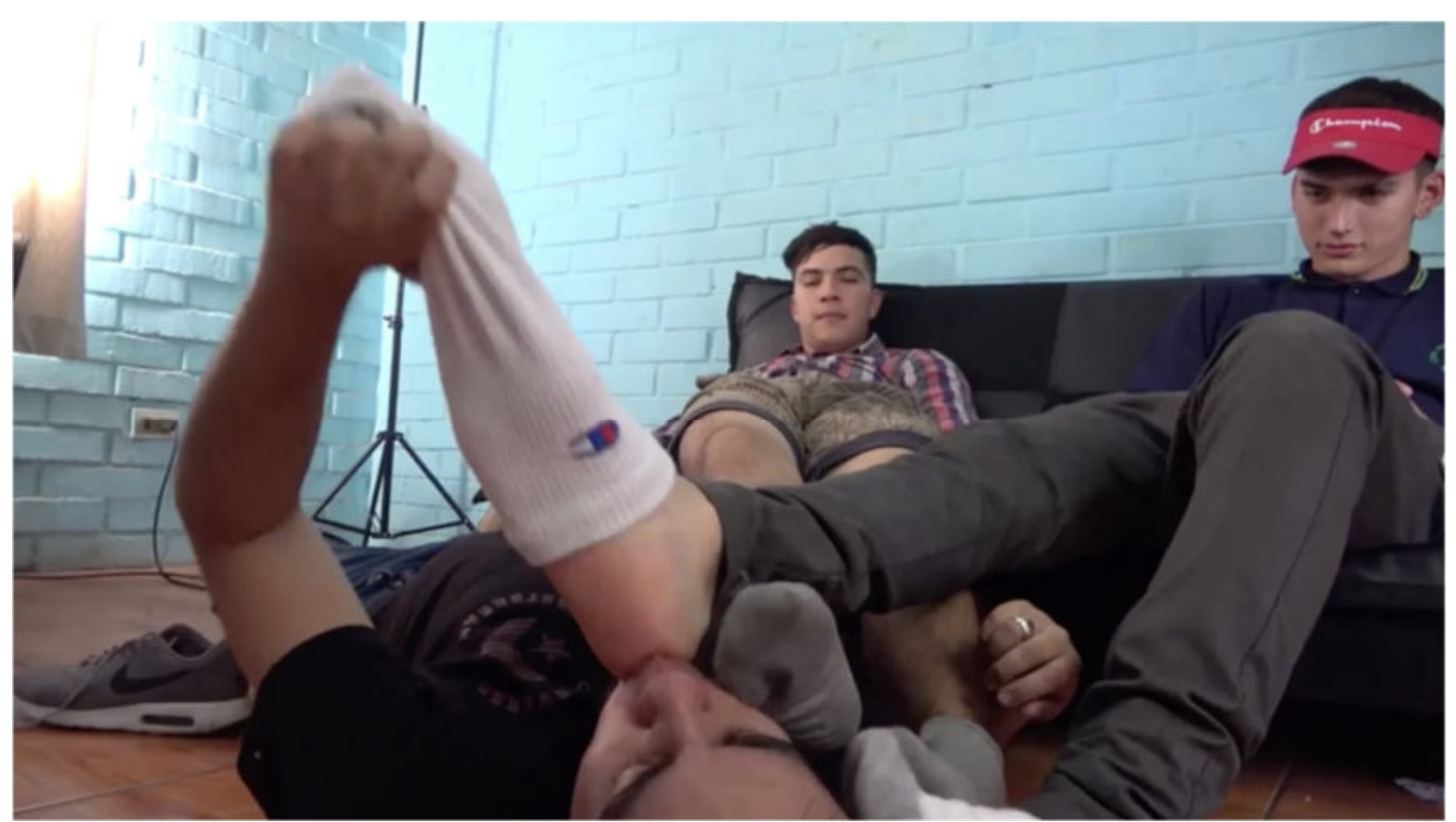

Fonte: Str8CrushFeet (2020).

\subsection{LADS FEET: DIMENSÃO PROTÉTICA, MATERIALIDADES DOS FLUIDOS}

O terceiro vídeo analisado está no site Lads Feet se parece com a interface do My Friends Feet, sobretudo, por que está no ar há 17 anos. Por isso, inclusive, oferece desconto especial para consumo do conteúdo no site por $\$ 17$ US dólares "para toda a vida", nos quais os primeiros 30 dias são oferecidos por \$34 US dólares que pode ser pago por cartão de crédito. Assim, o site oferece serviço de download e streaming de vídeos de 1080 pixels de resolução, 3 vídeos novos toda semana, imagens em pasta zipada para baixar e conteúdo 100\% exclusivo. Através de botão que expõe as abas de navegação no site, é possível visualizar os modelos, os vídeos, as fotos, as categorias, o conteúdo gratuito, o espaço para Onlyfans ${ }^{15}$, o contato com suporte, mais informações e aba de adesão à comunidade. Dentre as categorias, os vídeos são classificados como 3D, 4K, uniformes, chutando a bunda, pés descalços, bondage, adoração com botas, utilizando dildo, meias coloridas, pés sujos, "food stromping"16 "trampling"17 e entre outros.

Figura 9 - Recorte da primeira cena analisada no vídeo do Lads Feet.

\footnotetext{
15 Plataforma de serviço por assinatura onde os criadores de conteúdo vendem o seu material para assinantes. No caso da pornografia no fetiche da podolatria masculina, associo o que Ryan (2019) traz sobre o Onlyfans diante da forma como os perfis de mídia social podem adquirir capital econômico com conteúdo online, permitindo o acesso aos níveis de intimidade por meio do conteúdo monetizado.

${ }^{16}$ Expressão que traduz o que seria o fetiche de pisotear ou esmagar comidas com os pés.

${ }^{17}$ Palavra que traduz o fetiche sadomasoquista, que faz parte do BDSM e da podolatria, de ser pisoteado por alguém.
} 


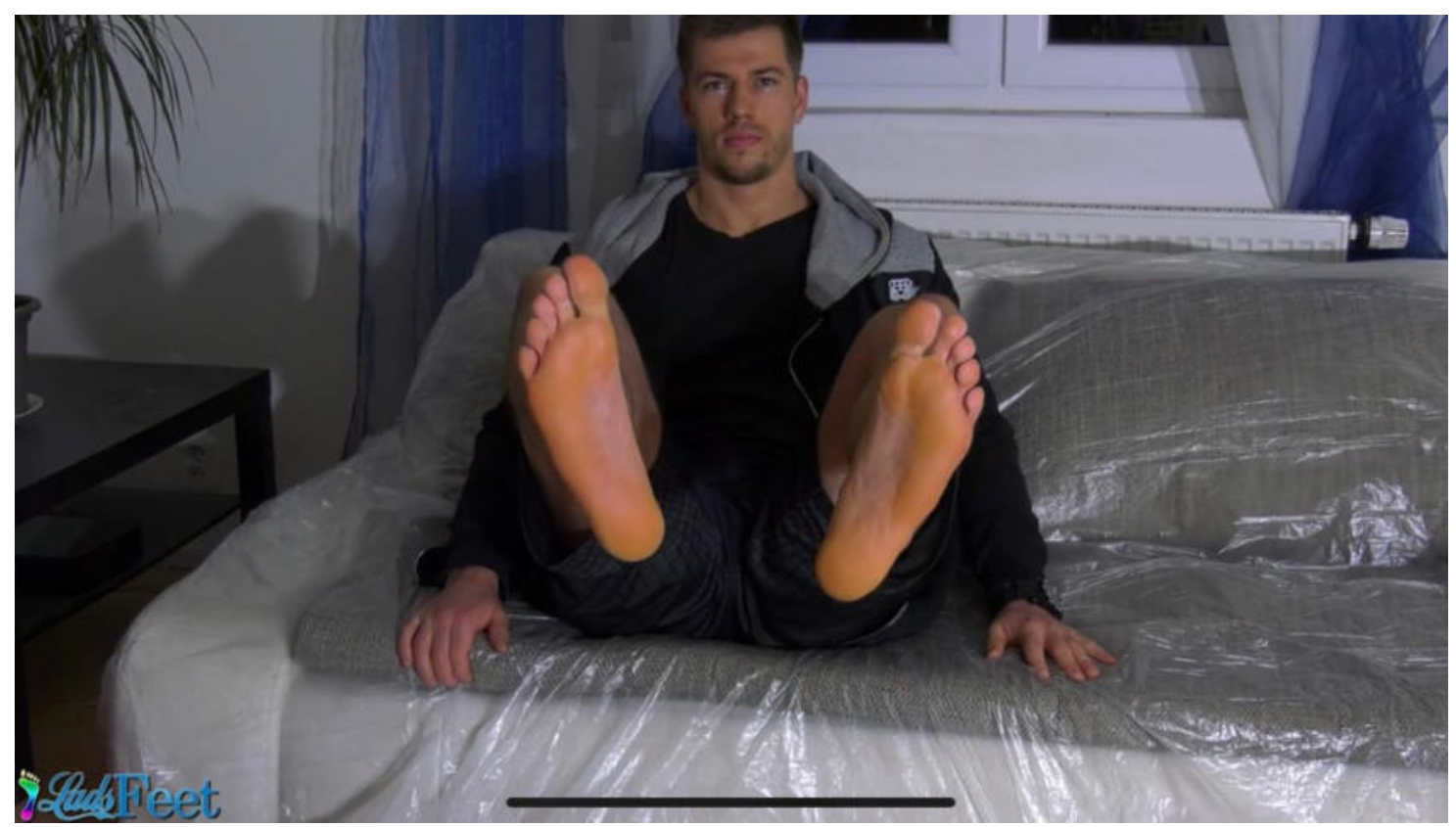

Fonte: Lads Feet (2020).

No vídeo, o modelo Dorian faz participa de um casting dos seus pés com resolução $4 \mathrm{~K}$ em vídeo publicado em 6 de abril de 2020 na duração de 6 minutos e 24 segundos. O site especifica todas características físicas do modelo na página que possui todos os vídeos dele. Dorian possui nacionalidade tcheca, 20 anos, $1,86 \mathrm{~cm}$ de altura, $89 \mathrm{~kg}$ e tamanho do pé tamanho 43 (11 UK) na medida do Brasil. No caso, o vídeo retrata de modo solo o exibicionismo do ator em mostrar os pés para a câmera. Gravado em plano aberto, Dorian aparece em uma sala de estar, sentado em um sofá coberto por um plástico, vestido com roupas casuais na cor preta, da camisa ao tênis. Em um primeiro momento, ele retira o tênis, depois as meias e levanta os pés para a câmera que foca em close. Sem cortes, o vídeo do Lads Feet não possui uma narrativa sincronizada ou caráter amador, de fato a produção procura fazer uma propaganda de como foi produzida a prótese dos pés do modelo como produto de venda ao mercado erótico do fetiche da podolatria. Assim, quando está descalço no vídeo, a equipe de produção entra em cena e coloca um depósito onde os pés do modelo ficam dentro e joga a massa do molde que cobre os membros.

Após, emassar o conjunto do molde no depósito com ajuda de outros dois homens da produção, a equipe retira os pés do modelo da massa que passa do estado líquido pastoso para sólido seco. Diante disso, ocorre um primeiro corte no vídeo que demonstra o processo de finalização da peça construído pelo molde do pé de Dorian, em plano detalhe. Em outra passagem de corte brusco a cena do sofá é retomada com o modelo com outra roupa e ao lado de alguém da equipe. O pé do modelo aparece descalço em cima do centro da sala enquanto, lentamente, o produtor retira o molde do depósito e coloca a prótese ao lado do pé. Lado a lado, o dildo do pé 
de Dorian e o próprio pé dele procuram representar de modo fidedigno a materialidade do desejo pelo vídeo. Desse modo, se em outros vídeos do site pornográfico o modelo aparece nas categorias de esmagamento, adoração e cócegas, quase todas as vezes nos cenários de academias, na atividade de box e malhação, a excreção do pé de Dorian como produto enaltecido pelo suor do corpo no cheiro do chulé produz além da encenação a materialidade do desejo pelo molde para contemplação do fetiche.

Figura 10 - Recorte da segunda cena analisada no vídeo do Lads Feet.

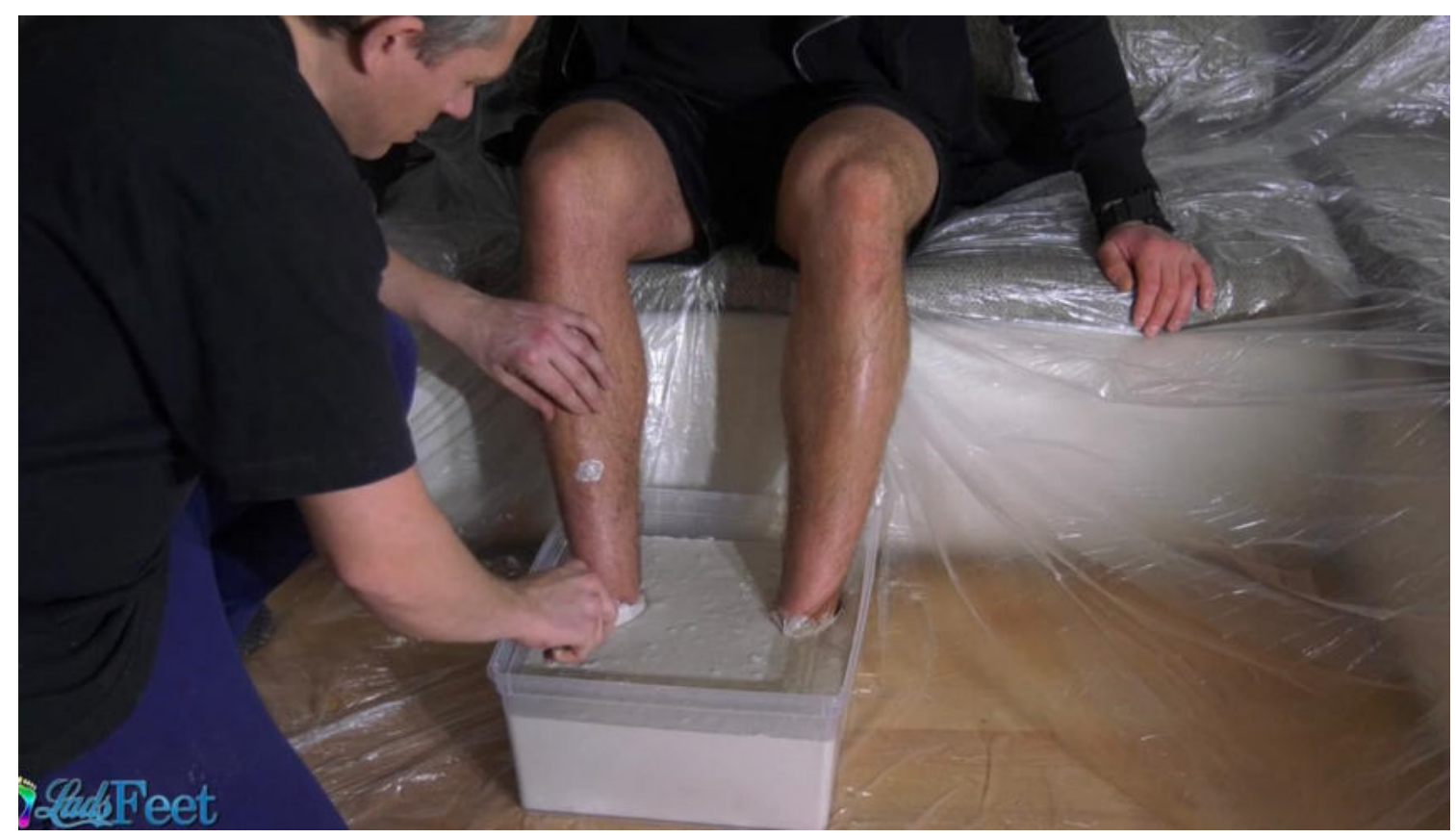

Fonte: Lads Feet (2020).

"Dorian tem uma cópia de silicone de seus pés feita para um cliente particular. Se você quiser comprar cópias personalizadas do meu modelo, envie-me um e-mail para um orçamento”, oferece o Lads Feet na descrição do vídeo de Dorian enquanto também destaca que o preço do molde varia dependendo do tamanho dos pés e do modelo utilizado para isso. Diante disso, relaciono que o Lads Feet aparece entre a produção pornográfica do My Friends Feet e do Str8crushfeet, pois ainda que siga a coreografia do script no rito da adoração pela construção encenada de situações similares ao primeiro, encontra na materialidade do dildo corporal off-line como desdobramento da subjetividade do desejo pela incorporalidade da representação visual e audiovisual da pornografia on-line. Dessa forma, a pornografia da podolatria mostra como a erótica do produto masculino excreto pela corporalidade do fetiche, enaltecido pelo desejo, pode criar próteses do erotismo que 
constroem efeitos de gêneros por meio das performances envolvidas nos processos e nas práticas pornográficas.

Figura 11 - Recorte da terceira cena analisada no vídeo do Lads Feet.

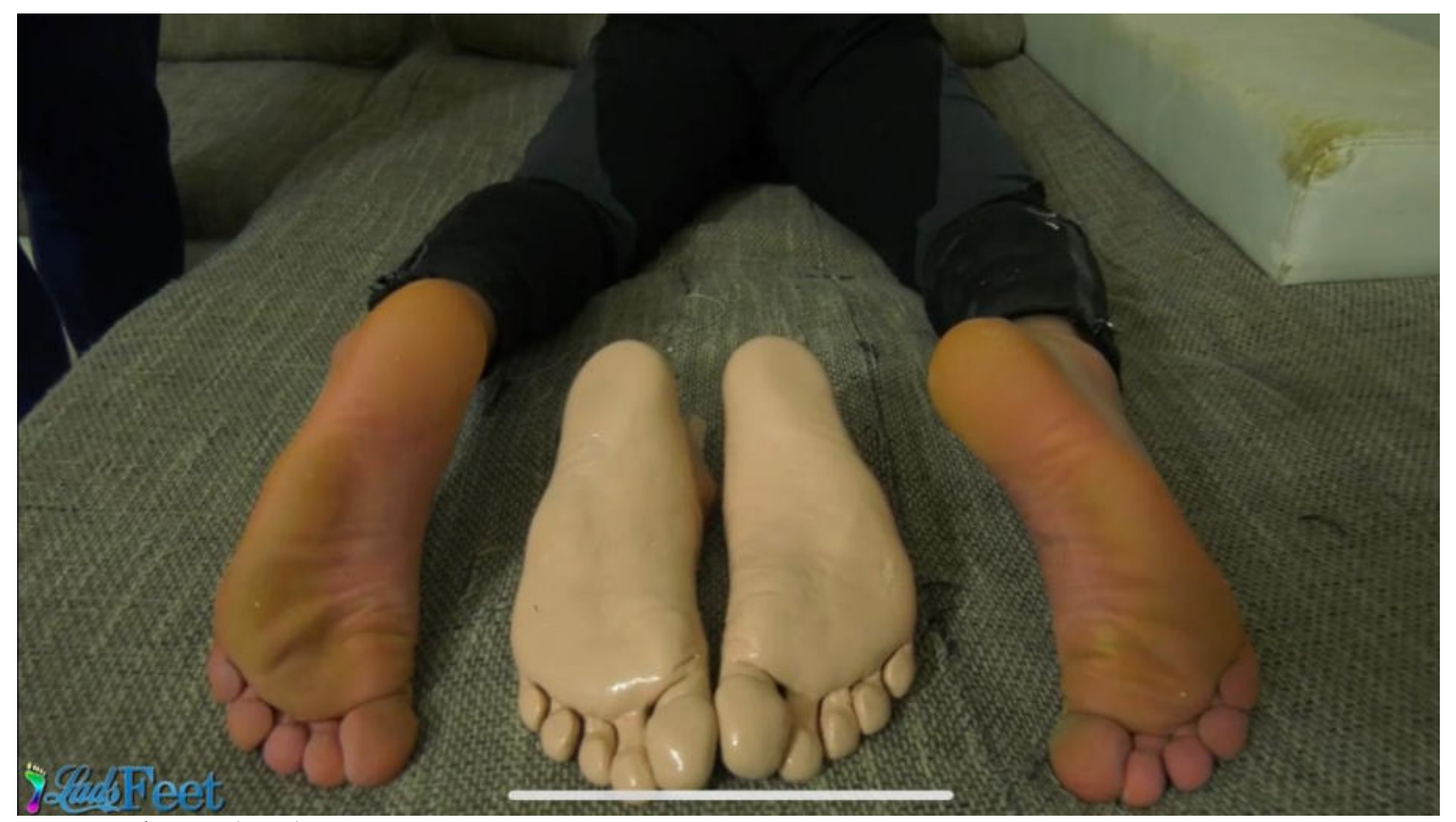

Fonte: Lads Feet (2020).

\section{CONSIDERAÇÕES FINAIS, CIGARRO COM MADONNA}

Ao fazer a mesma pergunta que Lopes (2020) diante do que eu aprendi com os filmes pornôs, falo também sobre o despertar para contextos sexuais que não conhecia diretamente. Talvez, arrisco dizer ainda que justamente por anteceder ao encontro desejado pelo instante atraído, a podolatria masculina tenha chamado minha atenção, pelos movimentos que envolvem os sentidos. Nos pés e nas línguas, o desejo aparece traçado nas telas entre o suor e a saliva, pelas imagens que extrapolam pelas imagens do excesso midiatizada na narrativa do desejo pelas corporalidades da pornografia.

Desse modo, considerei o bojo da analítica foucaultiana sobre a erotização do poder e a dessexualização do prazer para pensar na forma como as imagens da pornografia online, do fetiche da podolatria masculina, podem também ser uma ferramenta de problematização social e cultural. Pelos outros lugares pixelados do desejo, acredito que os simulacros incorporais entre as situações 
do ver, cheirar e sentir do produto masculino enaltecido pela corporalidade miditizada retorna o corpo a utopia de si, na medida em que usa os prazeres como forma de servir ao outro.

Assim, diante de três contextos específicos de produção pornográfica online, trouxe notas diante dos três modos de desejar pelas práticas do fetiche da podolatria masculina, nas suas respectivas dimensões das narrativas fílmicas da pornografia: coreografia, confissão e prótese. Embora tenha situado a produção dos três sites, vale destacar que a infinidade de imagens de pés na internet em diversos conteúdos pagos ou gratuitos. Porém, peso que por mais que a pornografia crie próteses da erótica dos produtos corporais masculinos, ainda não consegue trazer a experiência de rebaixamento pelo prazer na ordem do desejo que faça da língua a ponte de cheirar e lamber algum pé que caminhou até a boca e trouxe o que escorrega do corpo masculino no momento presente, do suor entre a pele e as meias, do cheiro entre as meias e o tênis. Afinal, como pede Madonna: "let my mouth go where it wants to" 18.

\section{REFERÊNCIAS}

BALESTRIN, Patria Abel; SOARES, Rosângela. "Etnografia de tela": uma aposta metodológica. In: MEYER, Dagmar Estermann; PARAÍSO, Marlucy Alves (Orgs.). Metodologias de pesquisas pós-críticas em educação. Belo Horizonte: Mazza Edições, 2012.

BALESTRIN, Patricia Abel. Tantas, sou só uma e sou tantas. Revista Polis e Psique, v. 1, n. 3, p. 85, 2011.

BARRETO, Victor Hugo de Souza. Erótica dos fluidos masculinos em práticas sexuais coletivas. Etnográfica, v. 23, n. 3, p. 717-738, 2019.

BUTLER, Judith. Corpos que importam: os limites discursivos do "sexo". São Paulo: N-1 edições, 2019.

DÍAZ BENÍTEZ, María Elvira. El quehacer porno en la construcción de imágenes de espectacularidad. Memoria y Sociedad, v. 17, p. 84-112, 2013.

\footnotetext{
18 Trecho da canção "Erotica” da Madonna que pode ser traduzido como "deixar a minha boca ir onde ela quiser".
} 
DÍAZ-BENÍTEZ, María Elvira. O espetáculo da humilhação, fissuras e limites da sexualidade. Mana, v. 21, n. 1, p. 65-90, 2015.

FOUCAULT, Michel. A história da sexualidade 1: a vontade de saber. Rio de Janeiro: Graal, 1988.

FOUCAULT, Michel. A história da sexualidade 2: o uso dos prazeres. Rio de Janeiro: Graal, 1984.

FOUCAULT, Michel. Ditos e escritos V - ética, sexualidade e política. Rio de Janeiro: Forense Universitária, 2012.

FOUCAULT, Michel. Michel Foucault, uma entrevista: sexo, poder e a política da identidade. verve, n. 5, 2004.

FOUCAULT, Michel. Microfísica do poder. Rio de Janeiro: Graal, 1996.

FOUCAULT, Michel. O corpo utópico, as heterotopias. São Paulo: N-1 edições, 2013.

FOUCAULT, Michel. Os anormais: curso no Collège de France (1974-1975). São Paulo: Martins Fontes, 2001.

GREGORI, Maria Filomena. Prazeres perigosos: o contrato e a erotização de corpos em cenários sadomasoquistas. Etnográfica, v. 19, n. 2, p. 247-265, 2015.

GUSMÃO, Roney. Madonna, "sex” e o fetichismo pós-moderno. Sociologia, Vol. XXXVIII, p. 71-87, 2019.

LEITE JÚNIOR, Jorge. A pornografia contemporânea e a estética do grotesco. Revista (In) Visível, p. 10-22, 2011.

LOPES, Denilson. Por que amo filmes pornôs. eRevista Performatus, ano 8, n. 21, jul. 2020.

MADONNA. Sex. New York: Time Warner, Maverick Records, 1992.

MAINGUENEAU, Dominique. O discurso pornográfico. São Paulo: Parábola Editorial, 2010. 
MEDEIROS, Afonso. O imaginário do corpo: entre o erótico e o obsceno, fronteiras líquidas da pornografia: Goiânia: FUNAPE, 2008.

PAIVA, Antônio Cristian Saraiva; RATTS, Júnior. O "cubanito" suspeito: a pornografia gay como ferramenta de problematização da realidade social e cultural. Revista Mídia e Cotidiano, v. 8, n. 8, p. 198-220, 2016.

PISCITELLI, Adriana. Prefácio. In: DÍAZ-BENÍTEZ, María Elvira; FÍGARI, Carlos Eduardo. (Org.). Prazeres dissidentes. Rio de Janeiro: Garamond, 2009, p. 11-20.

PRECIADO, Beatriz. Manifesto contrassexual. São Paulo: N-1 edições, 2014.

PRECIADO, Beatriz. Pornotopia: arquitectura y sexualidad en Playboy durante la Guerra Fría. Barcelona: Anagrama, 2010.

PRECIDO, Paul B. Testo junkie: sexo, drogas e biopolítica na era farmacopornográfica. São Paulo: N-1 edições, 2018.

REGES, Marcelo. Brazilian boys: corporalidades masculinas em filmes pornográficos de temática homoerótica. 2004. Tese (Doutroado em Antropologia Social) - Programa de PósGraduação em Antropologia Social, Universidade Federal de Santa Catarina, Florianópolis.

RIAL, Carmen. Antropologia e mídia: breve panorama das teorias de comunicação. Antropologia em primeira mão, v. 9, n. 74, 2004.

RYAN, Paul. Netporn and the Amateur Turn on onlyfans. In: Male Sex Work in the Digital Age. Palgrave Macmillan, Cham, 2019.

TRAVANCAS, Isabel. Fazendo etnografia no mundo da comunicação. In: BARROS, Antônio; DUARTE, J. (Org.). Métodos e técnicas de pesquisa em comunicação. São Paulo: Atlas, 2006, pp. 98-109.

VIANA, Luciene Galvão. A folia dos cus prolapsados: pornografia bizarra e prazeres sexuais entre mulheres. 2014. Dissertação (Mestrado em Antropologia) - Programa de Pós-Graduação em Antropologia, Universidade Federal de Pernambuco. Recife. 